\title{
FINANCIAL SIGNALING AND EARNINGS FORECASTS
}

\section{Iuliia Brushko}

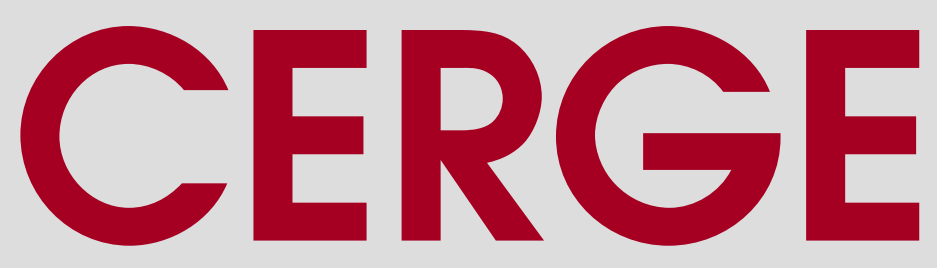

CenterforEconomic Research and Graduate Education

Academy of Sciences of the Czech Republic

Ec onomic Institute 


\title{
Working Paper Series 498 (ISSN 1211-3298)
}

\section{Financial Signaling and Earnings Forecasts}

\author{
Iuliia Brushko
}

\section{CERGE-EI}

Prague, November 2013 
ISBN 978-80-7343-302-4 (Univerzita Karlova. Centrum pro ekonomický výzkum a doktorské studium)

ISBN 978-80-7344-295-8 (Akademie věd České republiky. Národohospodářský ústav) 


\title{
Financial Signaling and Earnings Forecasts*
}

\author{
Iuliia Brushko ${ }^{\dagger}$
}

November 2013

\author{
CERGE-EI ${ }^{1}$
}

\section{Abstract}

This paper examines the extent to which financial signaling affects the analysts' and managers' forecast releases. The findings give evidence of heterogeneity of analysts' forecast errors between firms with strong financial indicators (high signal group), weak financial indicators (low signal group), and those with both positive and negative signals (mixed signal group). The paper further indicates that managers' forecast releases also depend on the type of the firm and that managers may try to use the heterogeneity in analysts' treatment. The findings also suggest that the analysts sometimes fail to adjust for managers' forecast biases and that is why may be misled by managers' forecasts. This provides evidence of inaccuracy on the part of analysts and potential gaming on information disclosures between analysts and managers.

Keywords: analysts' underreaction, earnings per share, analysts' forecast revisions, managers' forecast practices, earnings announcements

JEL classification: D84, G14, G17, G32, M40

*The work was financially supported by the grant SVV-2012-265 801, the Grant Agency of the Charles University grant \#341211, and the Czech Science Foundation project \# P402/12/G097 DYME Dynamic Models in Economics. I am thankful for the comments to Jan Hanousek, Jan Kmenta, and Olga Popova. All errors remaining in this text are the responsibility of the author.

${ }^{\dagger}$ E-mail: ibrushko@cerge-ei.cz

${ }^{1}$ Center for Economic Research and Graduate Education - Economic Institute, a joint workplace of the Charles University in Prague and the Academy of Sciences of the Czech Republic. Address: Politických vězňů 7, Prague 1, 110 00, Czech Republic 


\section{Abstrakt}

Tato práce zkoumá, do jaké míry finanční signalizace ovlivňuje předpovědi analytiků a manažerů. Nálezy svědčí o různorodosti chybovosti prognóz analytiků mezi firmami se silnými finančními ukazateli (skupina s vysokým signálem), firmami se slabými finančními ukazateli (skupina s nízkým signálem), a těmi s pozitivními i negativními signály (skupina se smíšenými signály). Článek dále indikuje, že předpovědi manažerů také závisí na typu podniku a že se manažeři mohou snažit využít heterogenity v chování analytiků. Výsledky také naznačují, že analytici někdy nepřizpůsobí své předpovědi chování manažerů a že toto je důvodem, proč mohou být uvedeni v omyl manažerskými prognózami. To je důkazem nepřesnosti na straně analytiků a případného strategického chování analytiků a manažerů ve zveřejňování informační. 


\section{Introduction}

The reaction to new information releases in the financial markets has created intense attention in the literature. The vast literature on this topic shows that investors do not fully incorporate all available information at once (referred to in the literature as overreaction or underreaction), which is evidenced by the existence of return drift of asset returns. The empirical evidence of overreaction and underreaction to new information has motivated researchers to reconsider assumptions of total rationality and homogeneity.

The phenomenon of underreaction or overreaction can be explained at least by three facts. The first is behavioral, and implies that people just cannot incorporate all relevant information at once, but do this rather with a time lag. Some usual (or expected) event will be perceived as natural and will a prompt the reaction at once, while an unexpected event will be more difficult to interpret, and this may cause either underreaction or overreaction. On the other hand, overreaction may also arise in a situation when investors get the signal of the same sign, because they may be too optimistic or too pessimistic about the information they get.

The second explanation for such a phenomenon can be the technical difficulties in putting accurate weights on the information signals that market participants receive simultaneously. As an example of technical or behavioral explanations, we can consider a situation in which the returns are predictable by the set of variables. In this case, it may be difficult for market participants to extract the information from the several signals which predict different future performance paths of the same stock.

The third explanation is the time relevance of the informational signals and inability to predict this relevance. Depending on the macroeconomic conditions some signals may have more predictive power at some point compared to other

signals, but under different macroeconomic conditions these predictive indicators 
may have no predictive power at all (Rapach et al. (2010a), Rapach et al. (2010b)). This means that we might be quite sure about the future performance of firms which have only high or only low indicators, while the situation might be not so clear for firms with both positive and negative signals. One might expect that the high or low signal groups may create biases toward optimism or pessimism, while the mixed signal group may prompt more unbiased market perception.

I contribute to the literature on analysts' accuracy by incorporating a financial signaling approach. In the reference to this approach, it should be mentioned that the managers of firms may or may not try to drive market expectations by choosing or manipulating the financial indicators. Regardless, these financial indicators may be perceived by the market agents as informative signals of the future performance of the firms. For these purposes, I consider three main groups of financial indicators which are indicators of profitability, operating efficiency, and capital structure.

As the second stage in my paper, I analyze the responses of managers to analysts' forecast accuracies or inaccuracies. If the analysts treat firms with low, high and mixed signals differently, we might expect that the managers would adjust their own forecasts in order to correct or, maybe, exploit the biases. While previous research considers the impact of macroeconomic conditions on the managers' forecast activity (Mikhail et al. 2009; Bergman \& Roychowdhury, 2008), I consider the managers' forecast releases from the standpoint of their response to the perception of analysts and the impact of managers' forecasts on the analysts.

By examining the analysts' earnings forecast revisions in the response to the managers' forecast announcements, we may gain insights into whether and how the analysts are influenced by the managers' forecasts. If the managers really release their forecasts strategically, the analysts may foresee such strategic behavior and revise their forecasts, adjusting for the possible forecast biases of managers depending on the types of the firms. The evidence of the heterogeneity of managers' forecast behavior and the analysts' forecast revisions in response, depending on the type of 
the firms could imply that there is a forecast disclosure game between analysts and managers.

Overall, the findings of the paper show, that the analysts' forecast errors distributions differ across low, high, and mixed signal groups. The impact of the momentum and reversal in the earnings change on the analysts' forecast errors is not equal across low, high and mixed signal groups. There is also evidence of heterogeneity in managers' forecast errors depending on the signal group of the firm and analysts' failure to adjust the earnings forecast revisions for the managers' biases.

While the previous research shows that the key indicators of balance sheet can predict future performance of firms, I show that it is not separate variables but rather their combination play a role in creating forecast biases of market participant including analysts and managers. In contrast to the previous literature, which shows the usefulness of the balance sheet as the source of information, I contribute to the existing literature by showing that balance sheet information may also create inefficiencies on the part of analysts and managers trying to exploit such inefficiencies. The findings of this paper may also motivate future research to identify the hierarchical structure of key finanical ratios predicting future earnings of firms, which may improve financial statement analysis and equity valuation practices.

The paper is organized as follows. In the second section the existing literature is discussed. The model and methodology are described in the third section. The fourth section addresses the issue of data and the sample selection. The fifth and sixth sections present the main findings. The seventh and the last section concludes the paper. 


\section{Literature Review}

There is a range of literature which aims to explain the analysts' forecast inaccuracy $^{1}$. Another area of research concentrates more on the asymmetries of market perception. Bagchee (2009), for example, finds asymmetry in the reaction of investors based on the performance of IPO of firms. If the firms upgrade, the investors react to new information faster, while if the firms downgrade they adjust their expectations approximately 3 times more slowly than after a positive signal. Larson and Mandura (2003) find that the reaction to the new information will be different depending on whether the information concerns losers (those stocks that have recently performed poorly) or winners (those stocks that perform well). They find that while losers experience underreaction from the market participants to the information, winners, on the contrary, are more likely to experience overreaction. These findings suggest that investors tend to act not only based on the information they get but also on their own judgments and beliefs. This means that not only does the information matters, but the history of the stocks also plays a role.

Moreover, Hirshleifer et al. (2009) find that analysts underreact more when there are earning announcements by other firms, which is explained by attention distraction: the more information there is, the more difficult it may be to process it. In comparison, I expect that it will be more difficult to process information about the same firm if it gives multidirectional signals. The difficulties in interpreting signals may be also noticed by the reaction of the market to the sequence of signals. If investors observe signals of the same sign several periods in a sequence, they may perceive it as a pattern and overreact, while after receiving signals of different signs, investors underreact, not knowing how to interpret contradictory signals (Potesman, 2001; Kaestner, 2006). While previous studies consider the time dimension for the sequence of news, it may be of interest to see the reaction to signals which are

\footnotetext{
${ }^{1}$ Among them are the works of Abarbanell and Bernard (1992), Mikhail et al. (2003), De Bondt and Thaler (1990), Benou (2003), Constantimou et al (2003), etc.
} 
sent simultaneously. For cases, when firms send only signals of the same sign, every subsequent signal will confirm a previous one. This may lead to the correct interpretation of the information or it may cause overreaction, while the signals of different signs may raise difficulties in interpreting their mutual effect and lead to underreaction.

When creating their forecasts, analysts make extensive use of all available information. Frankel and Lee (1998), for example, show that firms with particular characteristics such as higher past sales growth and higher market-to-book ratios receive higher optimistic forecasts by analysts. At the same time, Drake et al. (2011) and Jegadeesh et al. (2004) show that information from accounting statements can give the direction of short interest as well as analysts' recommendation adjustments. It is also commonly accepted that no particular financial ratio is informative unless it is considered as a part of the more complicated set of signals. This happens because the relative level of indicators rather than absolute value and/ or their combinations are informative. For example, small changes in leverage can imply adjustments to the optimal level, while dividend reductions can be perceived as new investments opportunities (and as a result future growth) or as an indicator of poor performance and a need for additional cash inflows. Small changes in sales and inventory can be the result of demand fluctuations, but are not necessarily informative about efficiency trends. It is this complexity of financial ratios that can explain the motivation to use the score or the sign of the ratios rather than the relative or absolute values of financial ratios used by Drake et al. (2011) and Jegadeesh et al. (2004), who show that stock returns can be predicted by the sign of financial ratios and that they are correlated with the score constructed from the sum of the signs.

The other motivation for using the score can be evidence that the combination of forecasts made on different variables is more accurate than those based on a particular variable (Rapach et al., 2010a). It has been shown that the simple models in which a set of regressions is used and returns in each regression are regressed on 
one explanatory variable and then the expected returns are calculated as equally weighted average of the predicted returns taken from this set of regressions work better than more elaborated models (Rapach et al. , 2010a). The underlying idea of their model is not the inclusion of all the variables into one regression, similar to Welch and Goyal (2008), but that the combination forecast of the returns is the weighted average of all the forecasts made by each variable separately. The intuition behind the better performance of forecast combinations is explained by the fact that individual specific variables fail to capture macroeconomic fluctuations, while the use of only macroeconomic variables does not take into account the specific economic performance and opportunities of firms, but the combination of both specifications delivers a synergic effect.

In addition to the intrinsic value of firms, the analysts' forecasts are influenced by market expectations (Mikhail et al., 2009; Lemmon and Portniaguina, 2006). While a range of authors establish the impact of market expectations on forecast accuracy and the fact that accuracy is the lowest during times when optimism is not explained by fundamental values (Mikhail et al., 2009), Bergman and Roychowdhury (2008) show that managers drive the analysts' forecasts upwards or downwards during periods of optimistic and pessimistic market expectations respectively. The authors explain this phenomenon by noting the fact that during low market expectations, the managers want to keep investors optimistic about the future of their firms, while during high market expectations they want firms to remain a bit undervalued. The authors also argue that the choice of managers to drive analysts' forecast is strategic, but it would be also natural to suspect that their strategic behavior is predetermined not only by the market expectations but also by the expected future prospects of firms and the uncertainty of these prospects (or in other words by the financial ratios and their combinations).

If the choice of managers to "walk" the forecasts up or down the forecasts is really strategic, the market (and especially such sophisticated players as analysts) may 
treat the disclosures of managers differently, since they may anticipate different reliability or implications of these forecasts depending on the types of firms. Managers of low signal firms may have much less incentives to drive the market expectation down even during optimistic periods, while the managers of high signal firms can afford to drive the analysts' forecasts downwards even during pessimistic periods.

The literature on the strategic forecast releases by managers shows that managers will avoid disclosure if they expect to achieve higher trading profits under the condition of non-disclosure, but at the same time they may disclose more actively under circumstances of higher volatility of earnings surprises and higher probability of liquidity shocks (Ma and Chang, 2007). Other documented reasons for disclosure decisions of managers include reputation effect, maintenance of stock prices, building of credibility, and conveying potential growth opportunities (Graham et. al., 2005). Dobler (2008), on the contrary shows, that the value of managers' forecasts should not be overestimated, since government regulation cannot impose a verifiability mechanism on the disclosure practices of managers.

In contrast, in my paper I concentrate on ways the financial characteristics of a company and analysts' perception of a firm can motivate managers to release their forecasts. In the disclosure games, different types of agents will behave in different ways. This may happen because by following the analysts, the managers may identify their biases and try to exploit any inefficiency. If I find evidence that managers' forecast activity is strategic, it might be interesting to study how analysts respond to such strategic behavior on the part of managers. By behaving strategically, managers try to drive the market in general, and the analysts in particular. One might expect that such strategic forecast releases may fail, because analysts may foresee the incentives for managers to manipulate the forecasts. 


\section{Methodology}

In reference to the accuracy of analysts' forecast, usually in the literature, regressions for estimating analysts' underreaction to earnings announcements (running forecast errors on previous period earnings changes) include only earnings changes, returns, lagged forecast errors, number of firms followed by analysts, and analysts' experience, brokerage size, forecast age, and forecast frequency. In fact, firms may give multidirectional and more complicated signals (referring to signals I mean key financial indicators): some may be positive and others negative simultaneously. This implies that correct interpretation of these signals separately without taking into account the rest may be a difficult task. Consider the following situation. Suppose that firm's earnings increased in the last quarter, but at the same time the leverage of the firm also increased in the same time period. On the one hand, the increase in the earnings may imply a momentum in the earnings, on the other, the higher leverage may also signal a future decrease of profits due to increased liabilities or that the increase of the leverage is the result of government quantitative easing policy. A small increase in the leverage may still be considered a positive signal if the leverage of a firm compared to the leverage of the firms in the same industry is low. Moreover, the change in leverage may be the result of the adjustments to the optimal level. Such adjustments may imply additional costs, resulting from such adjustments (Fischer et al., 1989), but firms deviating from optimal leverage ratio incur losses (Ju et al., 2002).

Small dividend policy changes can also be misleading. The dividends reductions can be considered a signal of investment and potential growth (Décamps \& Villeneuve, 2005) or an excess need for cash and poor performance. These findings are also supported by Simpson et al. (2009), who find evidence of overreaction hypotheses, uncertain hypotheses, overoptimism, and market efficiency after dividend announcements. Changes in inventory and sales can be the result of demand fluctu- 
ations rather than indicators of a firm's operating efficiency. That is why I cannot consider absolute changes but will rather consider the relative rates. In addition, I will not address the issue of the impact of separate variables, but rather how their combinations change the informational set.

The idea is to divide the sample into sub-samples according to the combination of positive and negative signals. Since high score portfolios (those with the highest number of positive signals) perform well ${ }^{2}$, one may use the scores as a screening device for the future performance of a firm. What is of interest is to see how the forecast accuracy of analysts differs across such groups of firms which may be considered potentially strong or weak performers and those which may fall into either category. The last group may be the most interesting to analyze since under the influence of positive and negative news, the analysts may have difficulties in processing information and interpreting new information, which may lead to higher errors in their forecasts, compared to the cases when all the signals have the same sign.

The groups (or subsamples) are formed based on the number of positive and negative signals. The following groups of economic variables are taken into account: profitability, operating efficiency, and capital structure ${ }^{3}$. The profitability ratios include sales profit margin (SPM), effective tax rate (ETR), interests to debt ratio (INTD), and dividends-to-earnings (DE) ratio. The operating efficiency ratios include asset turnover (TURNA), total accruals (TOTACR), capital expenditure (CAPEXP), correlation between costs and revenues (CCR), assets growth (AG), and depreciation-to-assets ratio (DA). The capital structure measures include book value to assets ratio (BVA), market-to-book value (BM), leverage (L), common stock

\footnotetext{
${ }^{2}$ For more details on the informativeness of financial signals for the portfolio performance, see Piotroski (2001), Jegadeesh (2004), Nguyen (2005), and Drake et al (2011).

${ }^{3}$ The set of signals include those variables which were found to be significant for earnings predictability by previous research (Nissim \& Penman, 2001; Dichev \& Tang, 2009; Fairfield et al., 1996; Ou, 1990; Foster, 1977). The details of constructing all the variables are provided in Table 1.
} 
interest (CSI), and minority stock interest (MSI) ${ }^{4}$.

Since the values of these variables may differ across industries, the score is assigned relative to the percentile level of a particular variable in the industry, where industries were determined by the 2-digit Standard Industry Classification Code. The appropriate score is given according to whether the indicator of the firm is below the 35 th percentile in the industry, between the 35 th and 65 th percentile, or is above the 65th percentile. Since for such variables as SPM, TURNA, DE, TOTACR, CAPEXP, ETR, INTD, AG, and CSI, the higher the value of these indicators, the more efficient the firm is, the score for each of these variables is 0,1 , or 2 for the firms that have this value below the 35 th percentile, within the bound of the 35 th and 65 th percentile or above the 65 th percentile respectively. In contrast, for such indicators as CCR, BVA, BM, L, DA, and MSI 2 points are given to the firms for which the level of this indicator is below the 35th percentile, 1 and 0 to those with these indicators in a range of the 35 th and 65 th percentile and above 65 th percentile, respectively ${ }^{5}$. Then each of the scores was scaled by the estimates obtained from running earnings per share on the lag of earnings per share and all the indicators (model 1 in Table 1; the estimates are provided in Table 2).

To draw a conclusion, I need only three main groups: those firms with a high number of low signals, those firms with a high number of high signals (high signals firms), and those with approximately the same number of high and low signals (mixed signal firms). To identify the groups, I follow the approach used by Piotroski (2001), Jegadeesh (2004), Nguyen (2005), Drake et al (2011) and construct a total score, which equals the sum of the signals. Those firms with a total score below the 25th percentile were considered to be the low signal group, firms with a total score above the 75th percentile were termed the high signal group, and those with a total

\footnotetext{
${ }^{4}$ The estimation model also includes such variables as lag of earnings per share and size of the firms, but I consider these variables as the state variable and do not take them into account when constructing the score of signals.

${ }^{5}$ There were missing values in the data for some of the financial indicators. For the missing values, the score 1 was assigned since it is considered to be neutral (neither positive, nor negative).
} 
score within the bounds of 45 th and 55 th percentile - the mixed signal group ${ }^{6}$.

As the first step, I use the Kolmogorov-Smirnov test in order to test the equality of distributions of the analysts' forecast errors for different types of firms, specifically, those with only relatively strong financial indicators, with only relatively weak financial indicators, and those with both strong and weak simultaneously.

All models used in the analysis are nested in the following general form specification $^{7}$ :

$$
Y=\alpha+\beta X+\gamma Z+\pi M+\eta
$$

where $Y$ is the vector of dependent variables. Matrix $X$ contains the control variables representing the characteristics of analysts. Matrix $Z$ consists of control variables representing the characteristics of the firms. Control variables of macroeconomic conditions are contained in matrix $M$. Vector $\eta$ consists of the error terms with zero mean and constant variance.

For my analysis of the accuracy of analysts' forecasts, I follow the specifications of Abarbanell \& Bernard (1992), Constantinou et al. (2003), Mikhail et al. (2009). While Abarbanell \& Bernard (1992), Constantinou et al (2003) use the simple OLS, Michail et al. (2009) use the fixed effect model. I use the first differencing, since it allows me to get rid of possible firm-analyst fixed effects as well as potential serial correlation of idiosyncratic errors.

In the model of of forecast accuracy of analysts, vector $Y$ represents the vector of

\footnotetext{
${ }^{6}$ Another approach to forming the groups was also considered: to form the low signal group only with high number of low signals, some neutral signals and no high signals; for the high signal group to include only firms with high number of high signals, some neutral signals and no low signals; and to construct the mixed signal groups of firms with both high numbers of both positive and negative signals. This approach may be in line with the research question, but could also lead to my working with very specific types of firms. On the contrary, although one may argue that following the approach I used, the low signal group may include a couple of high signals, and high signal group may include a few low signals, this approach nevertheless seems more plausible, since firms with even one or two negative (low) signals on the background of, say, 5 positive (high) signals will be perceived as rather financially strong and stable. The same argument can be applied to the low and mixed signal groups.

${ }^{7}$ All the estimation equations with the variable construction description are provided in the appendix, Table 1 .
} 
their forecast errors. Matrix $X$ with the analysts' characteristics includes lag of the forecast error in the previous quarter, brokerage size, forecast age, forecast frequency, general and firm experience of the analyst, and the number of firms followed by the analysts. The set of variables of matrix $Z$ include momentum and reversal in the earnings change. In my specification, matrix $Z$ also includes the total score and the standard deviations of scores based on which I am forming the signal groups. Control variables of macroeconomic conditions such as the fundamental and residual parts of consumer sentiment, and quarter dummies constitute matrix $M$.

At the next step, I analyze the forecast behavior of managers and analysts' responses to managers' forecast releases. In order to test whether the managers' forecast errors differ across types of firms, I use the ordinary least squared estimation of equation (1) which contains matrices $X$ and $M$ as the matrices of explanatory variables.

In this model, $Y$ is the vector of managers' forecast error. Among the firms' specific characteristics of matrix $X$ are the returns, standard deviation of returns, trading volume, standard deviation of trading volume, and average abnormal volume over 10 days prior to the managers' forecast release date, since Rogers and Stocker (2005) find that market information matters for the accuracy of the managers' forecast accuracy. Following Ma and Chang (2007), I include the standard deviation of analysts' forecasts. Combining the findings of Bergman and Roychowdhury (2008) with those of Mikhail et al (2009), I include such specific variables of firms as the average bid-ask spread and the standard deviation of bid-ask spread over 10 days prior to the managers' forecast release date, standard deviation of price over the last 120 days prior to the managers' forecast announcement date, dummy variable of loss in the previous quarter, dummy variable of negative managers' forecasts, interaction term of dummy of bad forecast and managers' forecast news, forecast horizon, industry concentration, insider transaction, and the size of the firms. Macroeconomic variables including fundamental and residual parts of consumer sentiment 
are contained in matrix $M$.

To test the impact of signal combination, I also include the standard deviation of the scores (those scores which I use in order to group the firms into sub samples of low, mixed and high signal groups). To test the affect of analysts' heterogeneity on the managers' incentives to release forecasts, I construct the variable of analysts' bias. For this purposes, I run model 1 of the accuracy of analysts' forecasts, save the explained and residual parts, and average them over analysts for a firm. While the predictable part should take into account the rational portion of analysts' forecast errors, the residual part should contain the irrational bias. This is because if the error term from model 1 is represented by:

$$
\eta_{j, j, t}=b_{i, j, t}+\epsilon_{i, j, t}
$$

where $b_{i, j, t}$ is the bias of analyst $i$ for firm $j$ in period $t$, and $\epsilon_{i, j, t}$ is the error term with zero mean and constant variance. Then averaging $\eta_{i, j, t}$ over analysts for a particular firm $i$ results in $\bar{\eta}_{j, t}=\bar{b}_{j, t}$ or, in other words, in the average bias for the firm.

To test the hypothesis that analysts discount managers' forecasts and that their discount factor will depend on the type of the firm, I use the robust least squared estimator for equation (1), but here $Y$ is the vector of analysts' adjustment and the estimation equation includes $X, Z$, and $M$ as matrices of explanatory variables.

As the response to the managers' forecasts, I consider only those analysts' forecasts which were releases within 5 days after the managers' forecasts. I restrict the analysts' forecast revisions to 5 a days window because later revisions are likely to be driven either by new information on the market, or as the result of analyst herding behavior in response to other analysts' revisions, or both. From the set of the explanatory variables of analysts' adjustments, managers' forecasts, managers' forecast range, ex-post managers' forecast errors, total signal score, and standard deviation of signals are of primary interest. Among the other firm's specific variables 
are the average stock returns and standard deviation of trading volume over 10 days prior to the analyst's forecast revision date, the average abnormal volume over 10 days prior to the analyst's forecast revision date, the average bid-ask spread and the standard deviation of bid-ask spread over 10 days prior to the analyst's forecast revision date, the standard deviation of price over the last 120 days prior to the analyst's forecast revision date, dummy variable of loss in the previous quarter, dummy variable of negative managers' forecasts, dummy variable of "bad" news provided by managers' forecast, interaction term of dummy of "bad" forecast and forecast news, forecast horizon, industry concentration, and insiders' transaction. One might expect that the analyst's accuracy characteristics may also have an impact on the analyst's adjustment. For this reason, I include all the explanatory variables from model (1). As in the previous models, I also include the fundamental and residual parts of consumer sentiment.

Lastly, I analyze the probability model of having the higher forecast error after the revision (for those analysts' who revised their forecasts) and use the same explanatory variables as the model with forecast adjustments by analysts, but vector $Y$ includes the indicator variables of 1 and 0 , if the forecast error is bigger or smaller after the revision, respectively.

\section{Data and Sample Selection}

For the analysis I take the quarterly data on earnings per share and all the accounting variables of the US firms from COMPUSTAT dataset. The data on analysts' earnings forecast are taken from I/B/E/S. For controlling the impact of the market expectations on the analysts and managers, the consumer confidence index was downloaded from the website of Understanding Diary Markets for which the data are available from June 1977 to October 2010. Prices, returns, and trading volumes 
are taken from CRSP dataset. The Fist Call database contains the data on the managers' earnings forecasts, while the insiders' transactions were taken from the Thomson Reuters database ${ }^{8}$.

For comparison of the forecast errors distributions, analysts' forecast accuracy, and analysis of the managers' forecasts, I am considering all the quarterly forecasts released by the end of the quarter, while analysts' adjustments I consider all the quarterly forecasts and all the revisions made within 5 days after managers' announcements.

In order to avoid the impact of outliers, I drop the observations in the following ways. In the analysis of the analysts' forecast errors distributions, I drop those observations with forecast errors in the first lowest percentile and the last highest percentile. For the model with the analysts' forecast determinants, I drop those observations for which Cook's distance is greater than 1. Analyzing the managers' forecasts, I also keep only the observations with the managers' forecasts errors above the 1-st percentile and below 99-th percentile. I drop the first and the last percentile of the analysts' adjustments for the analysis of revisions make by analyst and the accuracy of analysts after revision.

For the analysis of the analysts' forecast errors I have 464,873 firm-quarters observations in my sample, which represent 7,875 firms and 11561 analysts. In the entire sample there are 116,209 observations for the low signal, 44,171 observations for the mixed signal group and 120,150 observations for the high signal group. For model 3 with managers' forecasts, I have 278,542 observations, with 69,759, 32,019, and 83,975 observations in the low, mixed, and high signal groups respectively. The analysis of the forecast adjustments of analysts and their accuracy after adjustments was done with 40,970 observations, with 10,352 observations in the low signal group, 4,848 and 12,475 in the mixed and high signal groups.

\footnotetext{
${ }^{8}$ The descriptive statistics and the correlation matrix of the variables used are provided on request.
} 


\section{Statistical Comparison of Analysts' Forecast Er- rors}

\section{The effect of signal groups}

If analysts are influenced by financial indicators, their combinations, and/or their signs (positive (high) versus negative (low) signals), it is natural to suspect that the distribution of their forecast errors will be different across these types of firms. In my analysis, I decided to compare the distribution of 4 main groups:

- firms with mixed signals versus all the rest of the firms;

- firms with mixed signals versus firms with low signals;

- firms with mixed signals versus firms with high signals;

- firms with low signals versus firms with high signals.

The Kolmogorov-Smirnov test shows that the distributions of forecast errors are not the same for each of the above subgroups. The comparison of measures of the distributions from Table 3 indicates that the mean forecast error in absolute value is the highest for the high signal group and almost the same for the low and mixed signal groups. In level terms, the mean is the lowest for the low and mixed signal groups and the highest for the high signal group. This implies that the analysts tend to overestimate future performance the most for the high signal group ${ }^{9}$. The values of medians provide different information: while the median is negative for the low signal group, it is positive for the high and mixed signal groups. This finding might

\footnotetext{
${ }^{9}$ This inference comes from the construction of the variable forecast error which equals the difference between the actual and forecasted value of the earnings per share scaled by price and multiplied by 100 .
} 
be interesting, since one would expect the mean (median) of forecast errors to be the highest for the firms with the mixed signals. One of the possible explanations for this outcome might be the fact that in the extreme cases (in the case of only positive or only negative signals) analysts are more likely to overshoot or undershoot.

The standard deviation (variance) of the forecast errors is the highest for the high signal group and the spread of the forecast errors is the smallest for the group with low signals. From comparison of skewness, we can see that distribution is skewed to the left and the skewness to the left is highest for the firms in the high signal group. The negative skewness in our context implies that the analysts' forecasts frequently undershoot the actual value of earnings per share, though at times the forecasts are extremely overoptimistic. Kurtosis also signals us that the tails of distribution are the fattest for the low signal firms and the lowest for the firms with high signals, which in turn implies that the chances of extreme outcomes (forecast errors) are the highest for the low score group. Overall, we may conclude that analysts' forecasts biases depend on the types of firms and that their forecast errors are not homogenous across firms.

\section{The effect of changes in signals across groups}

It is definitely interesting to examine whether the analysts are confused by multidirectional signals. In contrast, it might be the case that sooner or later market participants (and especially sophisticated participants such as analysts) can infer the source of their confusion and adjust their information processing. This may result in more precise forecasts, even for firms with a confusing component. Motivated by these considerations, I decided to compare the distribution of the analysts' forecast errors depending on the changes in the scores. Further, analysts may react asymmetrically depending whether there were positive changes (for example when the score changed its value from 0 to 1 ) versus negative changes (for example when 
the score changed its value from 1 to 0 ). At this stage, I compare the distribution of the forecast errors for the following groups:

- firms without changes versus those with changes in the signals;

- firms without changes versus those with only negative changes;

- firms without changes versus those with only positive changes;

- firms with positive changes versus those with negative changes.

The Kolmogorov-Smirnov test shows that these subgroups do not have the same distribution functions. From Table 3, we may see that the mean forecast error for the subgroup which had changes in the signals is even more negative than that for firms which had no changes. The standard deviation, as expected, is higher for the subgroups with changes in the signals. The forecast errors are also more skewed to the left, but kurtosis is smaller for firms which did not have changes in the signals compared to firms which had some changes. Comparing the groups with only negative changes versus positive changes, the mean forecast error for the subgroup with only negative changes is more negative and the standard deviation is higher for this subgroup. The subgroup with only negative changes is less skewed to the left and has lower kurtosis.

\section{The effect of asymmetry of signal changes across groups: pos- itive versus negative changes}

To check the asymmetry in the analysts' responses to the positive and negative changes in the balance sheets, I test the equality of forecast errors distributions of firms which had: 
- a high number of positive changes and no negative changes versus the rest of the sample;

- no positive changes and a high number of negative changes versus the rest of the sample;

- an equal number of positive and negative changes versus the rest of the sample;

- a high number of positive changes and no negative changes versus no positive changes and a high number of negative changes;

- a high number of positive changes and no negative changes versus those with an equal number of positive and negative changes;

- no positive changes and a high number of negative changes versus those with an equal number of positive and negative changes.

Again, the Kolmogorov-Smirnov test shows that these subgroups do not have the same distribution functions. The mean forecast error (Table 3) is the smallest for the subgroup with a high number of negative changes in the signals, and the highest for firms with a high number of positive changes. In the absolute terms, the mean forecast error is highest for the subgroups with a high number of the negative changes in the signals, which implies that the analysts underreact the most to negative changes in the balance sheet of the firms. We can also see that the standard deviation in the forecast errors is highest for firms which had a high number of negative changes. The forecast errors for the subgroup with a high number of positive changes are more skewed to the left and have higher kurtosis compared to the subgroup with only a high number of negative changes and an equal number of positive and negative changes in the signals. 


\section{Empirical Results}

\section{Are analysts' perception of earnings the same across groups?}

The estimation results of the analysts' forecast accuracy model are presented in Table 4. Here the estimates next to variables including the total score, standard deviation of scores, momentum and reversal in the earnings changes are of the primary interest. From the regression for the whole sample, I find that the estimates of the total score and standard deviation of score are both significant and negative.

Comparing the estimates across low, mixed and high signal groups, I find that the estimates on the total score are significant and negative for the low signal group, but insignificant for the mixed and high signal groups. So ceteris paribus, the analysts produce more accurate forecasts for the low signal group when they observe an increase in signals, while the same increase in signals for the mixed or high signal group does not affect the precision of their forecasts. The estimates of the standard deviation of the total score is significant for the low and mixed signal groups only, being positive for the low signal groups and negative for the mixed signal group.

The estimates of momentum of earnings change were found to be significant for all groups, but I cannot reject the hypothesis that they are equal across groups. As for the reversal in earnings, it leads to higher analysts' inaccuracy in the analysts' forecasts for the low and high signal groups, but the estimate is insignificant for the mixed signal group.

\section{Do managers' forecast biases differ across groups?}

Tables 5 provides the estimates of managers' forecast error model (model 3). There are 5 main estimates of primary interest: total score, the standard deviation of scores, standard deviation of analysts' forecasts, analysts' bias, and predicted analysts' forecast error. All of these variables have different effects on the forecast 
releases of managers of different types of firms (all of the estimates except for the predicted part of analysts' forecast error were found to differ across groups).

Recalling that the managers' forecast error was defined as the difference between the actual level and the managers' forecast scaled by mean price, one might observe that the managers of the mixed signal groups tend to overestimate the earnings per shares with an increase in the score, while they underestimate earnings for the high signal group with an increase in the total score. The total score was not found to be significant for the low signal group.

The standard deviation of the scores should reveal the impact of the uncertainty associated with the future performance of the firm. Here I also find asymmetry in the managers' forecasts between managers of the low, mixed and high signal groups: managers tend to overestimate the future earnings per share with the increase in the heterogeneity of the signal for the low and high signal groups; the overestimation is higher for the high signal group. On the contrary, the managers of the mixed signal group underestimate future earnings with an increase in the uncertainty of the directions of the signals.

The increase in the standard deviation of the analysts' forecast errors does not affect the precision of the forecasts generated by managers of the low signal group, but it leads to overestimated forecasts for the mixed and high signal groups, with more optimistic forecasts for the high signal group.

The managers of the high signal group are influenced by the forecast bias of analysts and they tend to overestimate their forecasts when they observe higher analysts' forecast bias. The estimates of analysts' forecast bias for the low and mixed signal groups were not found to be significant.

With the increase in the predictable part of analysts' forecasts, the managers of the low and mixed signal groups tend to overestimate the future earnings per share and the estimates were not found to be different across groups. 


\section{Do the analysts' discount the managers' forecasts?}

Tables 6 and 7 contain the estimates from the model of analysts' forecast revisions and analysts' forecast accuracy upon managers' forecasts (model 4 and model 5). Upon managers' forecasts, the analysts update their forecasts upwards for all signal groups with the increase in the managers' earnings estimates. The estimates were not found to differentiate across different groups. The increase in the managers' forecasts was not found to be significant in the probability model of greater analysts' forecast errors after revision for any of the groups. Basically, the analysts' optimally extract the information from the managers' forecasts across groups.

When the managers provide upper and lower bounds of their forecasts, the analysts tend to revise their forecast upwards for the high and mixed signal groups. However, the managers' forecast range does not affect the probability of greater analysts' forecast errors after revision for the low signal groups. For the mixed and high signal groups, an increase in the managers' forecast range leads to higher probability of more significant analysts' forecast errors after the revision and this effect is greater for the mixed signal group. This suggests that the analysts tend to extract the information from the managers' forecast range optimally for the low signal group, but they may not be able to do this for the mixed and high signal groups.

If the managers release a point estimate and only lower bound for their forecast of future earnings per share, the analysts' revisions for the high signal group are not influenced by the differences in the earnings estimates and the lower bound of the earnings estimates. For the low and mixed signal group, they tend to revise upwards and the estimates were not found to be different for these two signal groups. For the low and mixed signal groups, the analysts forecast accuracy after revision is not affected by the managers' forecast range if managers provide only the earnings estimate and the lower bound of estimate, but the probability of the greater analysts' forecast after revision is smaller for the high signal group. 
With the increase in the ex-post managers' forecast errors, the analysts tend to revise upwards and the estimates are equal across groups. On the contrary, the probability of having a higher forecast error after the revision increases in the expost managers' forecast errors for all the groups. While effect of the increase is the highest for the mixed signal group, it does not differ across low and high signal groups.

The increase in the total signal score leads to the upwards revision of analysts' forecasts for the low signal group and has no effect on revisions of the mixed and high signal groups. The probability of having the higher forecast error after revision is not influenced by the increase in the total signal score across the signal groups. The increase in the heterogeneity of the signals leads analysts to revise downwards for the low signal group and upwards for the high signal groups. The revisions for the mixed signal group are not affected by an increase in the heterogeneity in signals. As for the precisions of the analysts' forecasts after revision, the probability of having higher forecast errors is not affected by the increase in the heterogeneity in signals for any of the groups.

\section{Conclusion}

This paper provided evidence of analysts' forecast biases which are driven by the financial indicators of the firm. While previous research tries to explain the analysts' forecast errors, I show that the information contained in earnings is perceived differently across firms. The result comes from the fact that when predicting future earnings of the firms, analysts use a set of indicators or information signals. When they obtain signals of the same sign (when all indicators predict prosperous or poor performance of the firm), one would expect that due to lower uncertainty about the firms' future performance, the analysts' forecast errors should be smaller. On the contrary, there is evidence that the analysts actually over- or underreact when creating their forecasts for these types of firms. 
Overall, the analysis yields the following findings. Firstly, the paper argues that the distributions of the analysts' forecast errors are not equal across firms with only low, only high, and mixed (with both, low and high) signals.

The paper also analyzes the impact of the analysts' forecast accuracy biases on managers' incentives to release forecasts and manipulate the market. There is evidence that the managers' earnings over- or underestimation is driven by variables including the total signal score, standard deviation of the signals, standard errors of the analysts' forecast errors, analysts' bias and predicted part of the analysts' forecast errors. The managers' forecasts, in their turn, have an impact on the analysts who may update their forecasts in response to them. While there is no evidence of differences in the effect of managers' point estimates of earnings on the analysts' adjusting their forecast across groups, there is the evidence of the different responses of analysts to the earnings uncertainty sent by managers in the form of forecasting lower and upper bounds for the future earnings. The managersanalysts responses to each other's forecast releases imply that there may be gaming on disclosure .

Overall, the paper indicates that the analysts' forecast biases depend on the signal group. The managers of the firms try to exploit these biases by releasing their own forecasts and tending to drive the analysts' forecasts. The analysts sometimes fail to realize the managers' biased forecasts and take into account these biases when revising their forecasts. 


\section{References}

Abarbanell, J.S., Bernard, V.L., 1992. Test of Analysts' Overreaction/Underreaction to Earnings Information as an Explanation for Anomalous Stock Price Behavior. Journal of Finance, 47 (3), pp. 1181-1207.

Bagchee, D., 2009. Investors Adjust Expectations around Sell-Side Analyst Revisions in IPO Recommendations. Journal of Financial Research, XXXII (1), pp. $53-70$.

Bergman, N., Roychowdhury, S., 2008. Investor Sentiment and Corporate Disclosure. Journal of Accounting Research, pp. 1057-1083.

Benou, G., 2003. Market Underreaction to Large Stock Price Declines: The Case of ADRs. Journal of Behavioral Finance, 4 (1), pp. 21-32.

Constantinou, W., Forbes, P., Skerratt, L., 2003. Analysts Underreaction in the United Kingdom. Financial Management, pp. 93-106.

De Bondt, W.F.M., Thaler, R. 1990. Do Security Analysts Overreact? American Economic Review, 80 (2), pp. 52-57.

Décamps, J.P., Villeneuve, S., 2005. Optimal Dividend Policy and Growth Option. IDEI Working Papers 369, Institut d'Économie Industrielle (IDEI), Toulouse.

Dichev, I.D., Tang, V.W., 2009. Earnings Volatility and Earnings Predictability. Journal of Accounting and Economics, 47, pp. 160-181.

Dobler, M., 2008. Credibility of Managerial Forecast Disclosure in Market and Regulated Settings. International Journal of Financial Services Management, 3(1), pp.83-98.

Drake, Michael S.; Rees, Lynn; Swanson, Edward P., 2011. Should Investors Follow the Prophets or the Bears? Evidence on the Use of Public Information by Analysts and Short Sellers. Accounting Review, 86(1), pp.101-130. 
Epstein, L.G., Noor, J., Sandroni, A., 2010. Non-Bayesian Learning. The B.E. Journal of Theoretical Economics, 10 (1), pp.1623-1645.

Fairfield, P.M., Sweeney, R.J., Yohn, T.L., 1996. Accounting Classification and the Predictive Content of Earnings. Accounting Review, 71(3), pp. 337-355.

Fischer, E., Heinkel, R., Zechner, J., 1989. Dynamic Capital Structure Choice: Theory and Tests. Journal of Finance, American Finance Association, 44(1), pp. $19-40$.

Foster, G., 1977. Quarterly Accounting Data: Time-Series Properties and PredictiveAbility. Accounting Review, 52(1), pp. 1-21.

Frankel, R., Lee, C.M.C., 1998. Accounting Valuation, Market Expectation, and Cross-Sectional Stock returns. Journal of Accounting and Economics, 25, pp. 283319.

Graham, J.R., Capbell, R.H., Rajgopal, S., 2005. The Economic Implication of Corporate Financial Reporting, Journal of Accounting and Economics, 40(1-3), pp.3-73.

Hirshleifer, D., Lim, S.S., Teoh, S.H., 2009. Driven to Distraction: Extraneous Events and Underreaction to Earnings News. Journal of Finance, 64(5), pp. 22892325.

Jegadeesh, N., J. Kim, S. D. Krische, and C. M. C. Lee. 2004. Analyzing the analysts: When do recommendations add value? Journal of Finance, 59(3), pp.10831124.

Ju, N., Parrino, R., Poteshman, A.M., Weisbach, M.S., 2002. Horses and Rabbits? Optimal Dynamic Capital Structure from Shareholder and Manager Perspectives. NBER Working Papers 9327, National Bureau of Economic Research, Inc.

Kaestner, M., 2006. Anomalies Price Behavior Following Earnings Surprises: Does Representativeness Cause Overreaction? Revue de L'assosiation Francaise de Finance, 27 (2), pp. 5-31. 
Larson, S.J., Mandura, J., 2003. What Drives Stock Price Behavior Following Extreme One-day Returns. Journal of Financial Research, XXVI (1), pp. 113-127.

Lemmon, M., Portniaguiana, E., 2006. Consumer Confidence and Asset Prices: Some Empirical Evidence. Review of Financial Studies, 19, pp. 1499-1523.

Ma, T., Chang, W.-S. (2007). A strategic Model of Insider's Forecast Disclosure Decision. 15th Conference on the Theories and Practices of Securities and Financial Markets, Kaohsiung, Dec.14-15, 2007.

Mikhail, M.B., Walter, B.R., Willis, R.H., 2003. The Effect of Experience on Security Analyst Underreaction. Journal of Accounting and Economics, 35, pp. $101-116$.

Mikhail, M.B., , 2009. Does Investor Sentiment Affect

Sell-Side Analysts' Forecast Accuracy?

Michayluk, D., Neuhauser, K.L., 2006. Investor Overreaction during Market Declines: Evidence from the 1997 Asian Financial Crisis. Journal of Financial Research, XXIX (2), pp. 217-234.

Mohanram, P.S., 2005. Separating Winners form Losers among Low Book-toMarket Stock using Financial Statement Analysis. Review of Accounting Studies, 10, pp. $133-170$.

Nissim, D., Penman, S.H., 2001. Ratio Analysis and Equity Valuation: From Research to Practice. Review of Accounting Studies, 6, pp. 109-154.

Nguyen, P., 2005. Market underreaction and predictability in the cross-section of Japanese stock returns. Journal of Multinational Financial Management, 15, pp. 193-200.

Ou, J.A., 1990. The Information Content of Non-earnings Accounting Numbers as Earnings Predictors. Journal of Accounting Research, 28(1), pp.144-163.

Piotroski, J.D., 2000. Value Investing: the Use of Historical Financial Statement Information to Separate Winners from Losers. Journal of Accounting Research, 38, pp. 1-41. 
Poterba, J.M., Summers, L.H., 1988. Mean Reversion in Stock Prices: Evidence and Implications. Journal of Financial Economics, 22(1), pp. 27-59.

Poteshman, A.M., 2001. Underreaction, Overreaction, and Increasing Misreaction to Information in the Options Markets. Journal of Finance, 56 (3), pp. 851-876.

Rapach, D.E., Strauss, J.K., Zhou, G., 2010a. Out-of-Sample Equity Premium Prediction: Combination Forecasts and Links to the Real Economy. Review of Financial Studies, 23 (2), pp. 821-862.

Rapach, D.E., Strauss, J.K., Tu, J., Zhou, G., 2010b. Industry Return Predictability: Is it There Our of Sample? Working Paper Series. Available at SSRN: http:// ssrn.com/ abstract $=1307420$, last access 20.10.2010.

Simpson, M.W., Emery, J.T., Moreno, J.F., 2009. Overreaction and Underreaction to REIT Dividend Announcements and the Role of Monetary Policy. Journal of Real Estate Portfolio Management, 15 (3), pp. 289-298.

Welch, I., Goyal, A., 2008. A Comprehensive Look at The Empirical Performance of Equity Premium Prediction. Review of Financial Studies, 21(4), pp. 1455-1508. 
Table 1: Models and variables used

\section{Model 1: Signal informativeness}

$$
\begin{array}{r}
E P S_{j, t}=\rho_{0}+\rho_{1} E P S_{j, t-1}+\rho_{2} S P M_{j, t-1}+\rho_{3} T U R N A_{j, t-1}+\rho_{4} B V A_{j, t-1}+ \\
+\rho_{5} B M_{j, t-1}+\rho_{6} L_{j, t-1}+\rho_{7} D E_{j, t-1}+\rho_{8} T O T A C R_{j, t-1}+\rho_{9} C A P E X P_{j, t-1}+ \\
+\rho_{10} S I Z E+\rho_{11} E T R_{j, t-1}+\rho_{11} C C R_{j, t-1}+\rho_{13} I N T D_{j, t-1}+ \\
+\rho_{14} A G_{j, t-1}+\rho_{15} C S I_{j, t-1}+\rho_{16} D A_{j, t-1}+\rho_{17} M S I_{j, t-1}+\varsigma_{j, t}
\end{array}
$$

\begin{tabular}{|c|c|}
\hline Variables & Description \\
\hline$E P S_{j, t}$ & $\begin{array}{l}\text { The earnings per share excluding extraordinary items in the } \\
\text { quarter, where } j \text { stands for firm } j \text { and } t(t-1) \text { for quarter } t \\
(t-1)\end{array}$ \\
\hline$S P M_{j, t-1}$ & $\begin{array}{l}\text { The sales profit margin is equal to operating income after } \\
\text { depreciation to sales }\end{array}$ \\
\hline$T U R N A_{j, t-1}$ & $\begin{array}{l}\text { The asset turnover is calculated as current sales divided by } \\
\text { total assets }\end{array}$ \\
\hline$B V A_{j, t-1}$ & $\begin{array}{l}\text { Book value, which is difference between total assets and } \\
\text { total liabilities, scaled by total assets }\end{array}$ \\
\hline$B M_{j, t-1}$ & $\begin{array}{l}\text { The market-to-book value equals to book value divided by } \\
\text { the product of the average number of shares outstanding } \\
\text { over the last quarter and the average share price over the } \\
\text { last quarter }\end{array}$ \\
\hline$L_{j, t-1}$ & $\begin{array}{l}\text { The leverage is the ratio of sum of long-term debt and debt } \\
\text { in current liabilities to total assets }\end{array}$ \\
\hline$D E_{j, t-1}$ & $\begin{array}{l}\text { The dividends-to-earnings ratio equals dividends divided by } \\
\text { earnings }\end{array}$ \\
\hline${\text { TOT } A C R_{j, t-1}}$ & $\begin{array}{l}\text { Total accruals are calculated as the change in the total } \\
\text { assets minus the change in total liabilities and minus the } \\
\text { change in the yearly average cash scaled by total assets }\end{array}$ \\
\hline$C A P E X P_{j, t-1}$ & $\begin{array}{l}\text { Capital expenditures are the ratio of yearly capital } \\
\text { expenditures to total assets }\end{array}$ \\
\hline$S I Z E_{j, t-1}$ & Natural logarithm of total assets \\
\hline$E T R_{j, t-1}$ & $\begin{array}{l}\text { Effective tax rate is calculated as one year moving average } \\
\text { income taxes to pretax income ratio }\end{array}$ \\
\hline$C C R_{j, t-1}$ & $\begin{array}{l}\text { The correlation between costs and revenues over the last } \\
\text { four quarters }\end{array}$ \\
\hline$I N T D_{j, t-1}$ & $\begin{array}{l}\text { Interests to debt ratio is calculated as the ratio of interests } \\
\text { to the sum of long-term debt and debt in current liabilities }\end{array}$ \\
\hline$A G_{j, t-1}$ & $\begin{array}{l}\text { Assets growth is equal to logarithm of total assets in the } \\
\text { current quarter to total assets in the previous quarter }\end{array}$ \\
\hline$C S I_{j, t-1}$ & $\begin{array}{l}\text { The common stock interest equals to income before } \\
\text { extraordinary items available to common stock holders to } \\
\text { common stockholder equity }\end{array}$ \\
\hline
\end{tabular}


Table 2 (continued): Models and variables used

\begin{tabular}{|l|l|}
\hline Variables & Description \\
\hline \hline$D A_{j, t-1}$ & $\begin{array}{l}\text { The depreciation-to-assets ratio is the depreciation scaled by } \\
\text { total assets }\end{array}$ \\
\hline$M S I_{j, t-1}$ & $\begin{array}{l}\text { The minority stock interest calculated as the ratio of } \\
\text { noncontrolling interests to common stockholder equity }\end{array}$ \\
\hline
\end{tabular}

\section{Model 2: Analyst inaccuracy}

$$
\begin{array}{r}
\text { FcErr }_{i, j, t}=\alpha_{0}+\alpha_{1} \text { FcErr }_{i, j, t-1}+\alpha_{2} \text { BrSize }_{i, t}+\alpha_{3} \text { FcAge }_{i, j, t}+ \\
+\alpha_{4} \text { FcFr }_{i, j, t}+\alpha_{5} \text { GenExp }_{i, t}+\alpha_{6} \text { FirmExp }_{i, j, t}+\alpha_{7} \text { NumFirm }_{i, t}+ \\
+\alpha_{8} \text { MomEarn }_{j, t}+\alpha_{9} \text { RevEarn }_{j, t}+\alpha_{10} \text { TotScore }_{j, t}+\alpha_{11} \text { SdTotScore }_{j, t}+ \\
+\alpha_{12} \text { FundSent }_{t}+\alpha_{13} \text { ResSent }_{t}+\sum_{k=2}^{4} \alpha_{k+12} q_{k}+\eta_{i, j, t}
\end{array}
$$

\begin{tabular}{|c|l|}
\hline \multicolumn{1}{|c|}{ Variable } & Description \\
\hline \hline \multicolumn{2}{|c|}{ Analyst's characteristics } \\
\hline$F c E r r_{i, j, t}$ & $\begin{array}{l}\text { The forecast error of analyst } i \text { for firm } j \text { in quartet } t \text { and it } \\
\text { is equal to the absolute value of the last forecast error of } \\
\text { analyst } i \text { for firm } j \text { in quarter } t \text { by the end of the fiscal } \\
\text { quarter multiplied by 100; the forecast error is defined as the } \\
\text { difference between the forecasted level and actual earnings } \\
\text { per share scaled by the by the mean stock price over } 10 \text { days } \\
\text { before the day of forecast announcement } 10\end{array}$ \\
\hline BrSize $_{i, t}$ & $\begin{array}{l}\text { The indicator variable of the brokerage house size for the the } \\
\text { analyst } i \text { is employed in quarter } t \text { and it equls } 1 \text { if the } \\
\text { number of analysts employed by the brokerage house is } \\
\text { above 10-th decile and } 0 \text { otherwise. }\end{array}$ \\
\hline$F c A g e_{i, j, t}$ & $\begin{array}{l}\text { The forecast age or the time interval between the forecast } \\
\text { release date of analyst } i \text { for firm } j \text { and the earnings } \\
\text { announcement date }\end{array}$ \\
\hline$F c F r_{i, j, t}$ & $\begin{array}{l}\text { The forecast frequency or the number of quarterly forecasts } \\
\text { analyst } i \text { released for firm } j \text { in the previous calendar year }\end{array}$ \\
\hline$G e n E x p_{i, t}$ & $\begin{array}{l}\text { The number of quarters for which analyst } i \text { released at least } \\
\text { one quarterly forecast prior to the release of the current } \\
\text { forecast }\end{array}$ \\
\hline
\end{tabular}

$\overline{12} \overline{\text { If }}$ the day of the week 10 days before the forecast announcement is Saturday or Sunday, I take the price 11 days or 9 days before the forecast respectively. 
Table 2 (continued): Models and variables used

\begin{tabular}{|c|c|}
\hline Variable & Description \\
\hline FirmExp $p_{i, j, t}$ & $\begin{array}{l}\text { The number of quarters for which analyst } i \text { released at least } \\
\text { one quarterly forecast for firm } j \text { prior to the release of the } \\
\text { current forecast }\end{array}$ \\
\hline NumFirm $_{i, t}$ & $\begin{array}{l}\text { The number of firms followed in the same 2-digit SIC } \\
\text { industry }\end{array}$ \\
\hline \multicolumn{2}{|r|}{ Firm's characteristics } \\
\hline MomEarn $_{j, t}$ & $\begin{array}{l}\text { The momentum of the previous period earnings change, } \\
\text { which is equal to the change in the earnings between } t-2 \\
\text { and } t-1 \text { if the change is of the same sign as the change in } \\
\text { the current period, between time interval } t-1 \text { and } t \text {, and } 0 \\
\text { otherwise }\end{array}$ \\
\hline $\operatorname{RevEarn}_{j, t}$ & $\begin{array}{l}\text { The reversal of the previous period earnings change, which is } \\
\text { equal to the change in the earnings between } t-2 \text { and } t-1 \text { if } \\
\text { the change is of the opposite sign as the change in the } \\
\text { current period, in a time interval between } t-1 \text { and } t \text {, and } 0 \\
\text { otherwise; }\end{array}$ \\
\hline TotScore $_{j, t}$ & The sum of scaled signals \\
\hline sdTotScore $_{j, t}$ & Standard deviation of signals \\
\hline \multicolumn{2}{|r|}{ Macroeconomic conditions } \\
\hline FundSent $_{t}$ & $\begin{array}{l}\text { The fundamental part of consumer sentiment and it is } \\
\text { constructed as the fitted value from the regression of } \\
\text { consumer sentiment on GDP growth, consumption growth, } \\
\text { labor income growth, default spread (difference between Baa } \\
\text { and Aaa rated corporate bonds), term spread as a difference } \\
\text { between } 10 \text { years government bonds and one month } \\
\text { Treasury bills yields, yields on the three month Treasury } \\
\text { bills, consumer price index change, CRSP value-weighted } \\
\text { index dividend yield }\end{array}$ \\
\hline ResSent $_{t}$ & $\begin{array}{l}\text { The residual part of consumer sentiment (the residuals from } \\
\text { the regression described above) }\end{array}$ \\
\hline$q_{2}, q_{3}, q_{4}$ & Quarter dummies \\
\hline
\end{tabular}

\section{Model 3: Managers'guidance}

$$
\begin{array}{r}
\text { ManFcErr }_{j, t}=\beta_{0}+\beta_{1} \text { sdSc }_{j, t}+\beta_{2} \text { sdAnF }_{j, t}+\beta_{3} \text { AnBias }_{j, t}+ \\
+\beta_{4} \text { AnFcErrPred }_{j, t}+\beta_{5} \text { FundSent }_{t}+\beta_{6} \text { ResSent }_{t}+\beta_{7} \text { Ret }_{j, t}+ \\
+\beta_{8} \text { sdRet }_{j, t}+\beta_{9} \text { Vol }_{j, t}+\beta_{10} \text { sdVol }_{j, t}+\beta_{11} \text { AbnVol }_{j, t}+\beta_{12} \text { AbnRet }_{j, t}+ \\
+\beta_{13} \text { sdAbnRet }_{j, t}+\beta_{14} \text { BASpr }_{j, t}+\beta_{15} \text { sdBASpr }_{j, t}+\beta_{16} \text { sdPrc }_{j, t} \\
+\beta_{17} \text { InsTrans }_{j, t}+\beta_{18} \text { dLoss }_{j, t}+\beta_{19} d \text { LossF }_{j, t}++\beta_{20} d \text { BadNews }_{*} \text { News }_{j, t} \\
+\beta_{21} \text { FcHor }_{j, t}+\beta_{22} \text { IndConc }_{j, t}+\beta_{23} \text { Size }_{j, t}+\omega_{j, t}
\end{array}
$$


Table 2 (continued): Models and variables used

\begin{tabular}{|c|c|}
\hline Variables & Description \\
\hline $\operatorname{ManFcErr}_{j, t}$ & $\begin{array}{l}\text { The managers' forecast error is the difference between the } \\
\text { actual and the forecasted level scaled by the average price } \\
\text { over } 10 \text { days prior to managers' forecast announcement date } \\
\text { and multiplied by } 100 \text {. }\end{array}$ \\
\hline$s d S c_{j, t}$ & $\begin{array}{l}\text { The standard deviation of the score for firm } j \text { in quarter } t \\
\text { which I use for dividing the sample into sub samples }\end{array}$ \\
\hline$s d A n F c_{j, t}$ & $\begin{array}{l}\text { The standard deviation of the analysts' forecasts for firm } j \\
\text { in quarter } t \text { known to the market on the day of the } \\
\text { managers' forecast release }\end{array}$ \\
\hline AnBias $_{j, t}$ & $\begin{array}{l}\text { The residual part from model } 3 \text {, averaged over analysts for } \\
\text { firm } j \text { in period } t \text {. }\end{array}$ \\
\hline AnFcErrPred $_{j, t}$ & $\begin{array}{l}\text { The explained part from model } 3 \text {, averaged over analysts for } \\
\text { firm } j \text { in period } t \text {. }\end{array}$ \\
\hline $\operatorname{Ret}_{j, t}$ & $\begin{array}{l}\text { The return for holding the stock of firm } j \text { in quarter } t \text { for the } \\
10 \text { days window prior the managers' forecast announcement } \\
\text { date (capital gain on the stock) }\end{array}$ \\
\hline sdRet $_{j, t}$ & $\begin{array}{l}\text { The standard deviation of the holding return for the firm's } j \\
\text { stock in quarter } t \text { during the } 10 \text { day window prior to the } \\
\text { managers' forecast announcement date }\end{array}$ \\
\hline$\overline{V o l} l_{j, t}$ & $\begin{array}{l}\text { The average ratio of stock trading volume to the number of } \\
\text { shares outstanding of firm } j \text { in quarter } t \text { over the } 10 \text { days } \\
\text { window prior to the managers' forecast announcement date }\end{array}$ \\
\hline$s d V o l_{j, t}$ & $\begin{array}{l}\text { The standard deviation of the ratio of stock trading volume } \\
\text { to the number of shares outstanding of firm } j \text { in quarter } t \\
\text { over the } 10 \text { days window before the managers' forecast } \\
\text { announcement date }\end{array}$ \\
\hline$A b n V o l_{j, t}$ & $\begin{array}{l}\text { The average abnormal trading volume for firm } j \text { in quarter } t \\
\text { over } 10 \text { days window prior to the managers' forecast } \\
\text { announcement }\end{array}$ \\
\hline$B A S p r_{j, t}$ & $\begin{array}{l}\text { The average bid-ask spread for the stock of firm } j \text { in quarter } \\
t \text { over } 10 \text { days window prior to the managers' forecast } \\
\text { announcement }\end{array}$ \\
\hline$s d B A S p r_{j, t}$ & $\begin{array}{l}\text { The standard deviation of bid-ask spread for the stock of } \\
\text { firm } j \text { in quarter } t \text { over } 10 \text { days window prior to the } \\
\text { managers' forecast announcement }\end{array}$ \\
\hline$s d P r c_{j, t}$ & $\begin{array}{l}\text { The standard deviation of stock price of firm } j \text { in quarter } t \\
\text { over } 120 \text { days window prior to the managers' forecast } \\
\text { announcement }\end{array}$ \\
\hline$s d P r c_{j, t}$ & $\begin{array}{l}\text { The standard deviation of stock price of firm } j \text { in quarter } t \\
\text { over } 120 \text { days window prior to the managers' forecast } \\
\text { announcement }\end{array}$ \\
\hline InsTrans $_{j, t}$ & $\begin{array}{l}\text { The value of insiders transactions of firm's } j \text { securities over } \\
10 \text { days prior to the managers' forecast announcement date } \\
\text { which is equal the sum of purchases minus sales. }\end{array}$ \\
\hline
\end{tabular}


Table 2 (continued): Models and variables used

\begin{tabular}{|c|c|}
\hline Variables & Description \\
\hline$\overline{d \operatorname{Loss}_{j, t}}$ & $\begin{array}{l}\text { The dummy variable which is equal } 1 \text {, if firm } j \text { had negative } \\
\text { earnings in the previous quarter, and } 0 \text { otherwise }\end{array}$ \\
\hline$d \operatorname{LossF}_{j, t}$ & $\begin{array}{l}\text { The dummy variable of negative forecast which is equal } 1 \text {, if } \\
\text { the firm's } j \text { managers' forecast is negative, and } 0 \text { otherwise }\end{array}$ \\
\hline $\begin{array}{l}d B a d N e w s * \\
\quad N e w s_{j, t}\end{array}$ & $\begin{array}{l}\text { The interaction term of dummy variable of bad news and } \\
\text { forecast news for firm } j \text { in quarter } t\end{array}$ \\
\hline $\mathrm{FcHor}_{j, t}$ & $\begin{array}{l}\text { The time interval between the managers' forecast release day } \\
\text { and and of the fiscal quarter for firm } j \text { in quarter } t\end{array}$ \\
\hline IndConc $_{j, t}$ & $\begin{array}{l}\text { The industry concentration of sales measured by the } \\
\text { herfindahl index for firm } j \text { in quarter } t\end{array}$ \\
\hline Size $_{j, t}$ & $\begin{array}{l}\text { The size of firm } j \text { in quarter } t \text { which is equal natural } \\
\text { logarithm of total assets }\end{array}$ \\
\hline
\end{tabular}

\section{Model 4: Analysts' adjustment}

$$
\begin{aligned}
& A n A d j_{i, j, t}=\delta_{0}+\delta_{1} \operatorname{ManF}_{j, t}+\delta_{2} \text { ManFcRan }_{j, t}+\delta_{3} \text { ManFcRanLow }_{j, t}+ \\
& +\delta_{4} \text { ManErr }_{j, t}+\delta_{5} \text { TotS }_{\text {core }}{ }_{j, t}+\delta_{6} s d S c_{j, t}+\delta_{7} s d A n F c_{j, t}+\delta_{8} \text { FundSent }_{t}+ \\
& +\delta_{9} \operatorname{ResSent}_{t}+\delta_{10} \operatorname{Ret}_{j, t}+\delta_{11} \text { sdRet }_{j, t}+\delta_{12} \operatorname{Vol}_{j, t}+\delta_{13} s d V o l_{j, t}++ \\
& +\delta_{14} A b n V o l_{j, t}+\delta_{15} B A S p r_{j, t}+\delta_{16} s d B A S p r_{j, t}+\delta_{17} s d \operatorname{Prc}_{j, t}+ \\
& +\delta_{18} \text { InsTrans }_{j, t}+\delta_{19} d \text { Loss }_{j, t}+\delta_{20} d \operatorname{LossF}_{j, t}+\delta_{21} d \text { BadNews }_{j, t}+ \\
& +\delta_{22} d B a d N e w s * N_{e w s}, t+\delta_{23} \text { FcHor }_{j, t}+\delta_{24} \text { IndConc }_{j, t}+\delta_{25} \text { Size }_{j, t} \\
& +\delta_{26} \text { Bold }_{i, j, t}+\delta_{27} F_{c A g e}{ }_{i, j, t}+\delta_{28} F_{c F r} r_{i, j, t}+\delta_{29} F_{i r m E x p} \operatorname{Exp}_{i, j}+\varepsilon_{i, j, t}
\end{aligned}
$$

\begin{tabular}{|c|l|}
\hline Variable & Description \\
\hline \hline$A n A d j_{i, j, t}$ & $\begin{array}{l}\text { The ordered outcome of analyst's } i \text { adjustment of his } \\
\text { forecast for firm } j \text { in quarter } t \text {; the adjustment, in its turn, is } \\
\text { equal to the difference between new forecast and the old one; }\end{array}$ \\
\hline${\text { ManF } c_{j, t}}^{\text {The managers' forecast of firm } j \text { in quarter } t}$ \\
\hline${\text { ManFcRan } \text { Tan }_{j, t}}_{j, t}$ & $\begin{array}{l}\text { The managers' forecast range and equals the difference } \\
\text { between the upper and the lower bound managers forecast if } \\
\text { both estimates are available and zero otherwise } \\
\text { managers' forecast if only the forecast and the lower bound } \\
\text { of forecast are available and zero otherwise }\end{array}$ \\
\hline ManErr $_{j, t}$ & $\begin{array}{l}\text { Expost managers' forecast error which is equal to the } \\
\text { difference between the actual and forecasted level scaled by } \\
\text { the mean price over the 10 days before the managers' } \\
\text { forecast announcement }\end{array}$ \\
\hline
\end{tabular}


Table 2 (continued): Models and variables used

\section{Model 5: Analysts' Accuracy after Revision}

$$
\begin{aligned}
& \text { AnAccRev }_{i, j, t}=\gamma_{0}+\gamma_{1} \operatorname{ManF}_{j, t}+\gamma_{2} \operatorname{ManFcRan}_{j, t}+\gamma_{3} \operatorname{ManFcRanLow}_{j, t}+ \\
& +\gamma_{4} \text { ManErr }_{j, t}+\gamma_{5} \text { TotScore }+\gamma_{6} s d S c_{j, t}+\gamma_{7} s d A n F c_{j, t}+\gamma_{8} \text { FundSent }_{t}+ \\
& +\gamma_{9} \operatorname{ResSent}_{t}+\gamma_{10} \operatorname{Ret}_{j, t}+\gamma_{11} \text { sdRet }_{j, t}+\gamma_{12} \operatorname{Vol}_{j, t}++\gamma_{13} s d V o l_{j, t} \\
& +\gamma_{14} A b n V o l_{j, t}+\gamma_{15} B A S p r_{j, t}++\gamma_{16} s d B A S p r_{j, t}+\gamma_{17} s d \operatorname{Prc}_{j, t}+ \\
& +\gamma_{18} \text { InsTrans }_{j, t}++\gamma_{19} d \text { Loss }_{j, t}+\gamma_{20} \text { dLossF }_{j, t}+\gamma_{21} d \text { BadNews }_{j, t}+ \\
& +\gamma_{22} \text { dBadNews } * \text { News }_{j, t}+\gamma_{23} \text { FcHor }_{j, t}+\gamma_{24} \text { IndConc }_{j, t}+\gamma_{25} \text { Size }_{j, t}+ \\
& +\gamma_{26} \text { Bold }_{i, j, t}+\gamma_{27} F_{c A g e} e_{i, j, t}+\gamma_{28} F_{c F r} r_{i, j, t}+\gamma_{29} F_{i r m E x p} \operatorname{Ex}_{i, j}+\epsilon_{i, j, t}
\end{aligned}
$$

\begin{tabular}{|c|l|}
\hline Variable & Description \\
\hline \hline$A n A c c R e v_{i, j, t}$ & $\begin{array}{l}\text { The dummy variable which equals } 1 \text { if the absolute value of } \\
\text { analyst's } i \text { forecast for firm } j \text { after revision is bigger than the } \\
\text { one before revision and } 0 \text { otherwise }\end{array}$ \\
\hline
\end{tabular}


Table 2: Signal informativeness

VARIABLES EPS

\begin{tabular}{|c|c|}
\hline$E P S_{\text {_lag }}$ & $\begin{array}{c}0.001^{* * *} \\
(0.000)\end{array}$ \\
\hline$S P M$ & $\begin{array}{c}0.000^{* * * *} \\
(0.000)\end{array}$ \\
\hline$T U R N A$ & $\begin{array}{c}0.239^{* * *} \\
(0.004)\end{array}$ \\
\hline$B V A$ & $\begin{array}{c}-0.076^{* * *} \\
(0.006)\end{array}$ \\
\hline$B M$ & $\begin{array}{c}-0.237^{* * *} \\
(0.042)\end{array}$ \\
\hline$L$ & $\begin{array}{c}-0.286^{* * *} \\
(0.007)\end{array}$ \\
\hline$D E$ & $\begin{array}{c}0.000^{* * *} \\
(0.000)\end{array}$ \\
\hline TOT ACR & $\begin{array}{c}0.083^{* * *} \\
(0.009)\end{array}$ \\
\hline$C A P E X P$ & $\begin{array}{c}0.123^{* * *} \\
(0.016)\end{array}$ \\
\hline$S I Z E$ & $\begin{array}{c}0.088^{* * *} \\
(0.000)\end{array}$ \\
\hline ETR & $\begin{array}{c}0.001^{* * *} \\
(0.000)\end{array}$ \\
\hline$C C R$ & $\begin{array}{c}-0.000^{* * *} \\
(0.000)\end{array}$ \\
\hline$I N T D$ & $\begin{array}{c}0.000 * * * \\
(0.000)\end{array}$ \\
\hline$A G$ & $\begin{array}{c}0.083^{* * *} \\
(0.007)\end{array}$ \\
\hline$C S I$ & $\begin{array}{c}0.000^{* * *} \\
(0.000)\end{array}$ \\
\hline$D A$ & $\begin{array}{c}-1.616^{* * *} \\
(0.067)\end{array}$ \\
\hline$M S I$ & $\begin{array}{c}-0.000^{* * *} \\
(0.000)\end{array}$ \\
\hline Constant & $\begin{array}{c}-0.271^{* * *} \\
(0.006)\end{array}$ \\
\hline Observations & 204,903 \\
\hline R-squared & 0.186 \\
\hline
\end{tabular}


Table 3: Distribution parameters of the subgroups

\begin{tabular}{|c|c|c|c|c|c|c|}
\hline & \multicolumn{6}{|c|}{ Parameter } \\
\hline Group & Mean & Median & $\begin{array}{c}\text { Standard } \\
\text { devia- } \\
\text { tion }\end{array}$ & Variance & Skewness & Kurtosis \\
\hline $\begin{array}{l}\text { Low signals } \\
\text { group }\end{array}$ & -0.188 & -0.069 & 2.150 & 4.623 & -4.623 & 37.823 \\
\hline $\begin{array}{l}\text { Mixed signals } \\
\text { group }\end{array}$ & -0.189 & 0.071 & 2.202 & 4.851 & -4.823 & 37.161 \\
\hline $\begin{array}{l}\text { High signals } \\
\text { group }\end{array}$ & -0.222 & 0.072 & 2.239 & 5.015 & -4.830 & 36.538 \\
\hline $\begin{array}{l}\text { Group which } \\
\text { did not have } \\
\text { changes in the } \\
\text { signals }\end{array}$ & -0.167 & 0.071 & 2.123 & 4.511 & -4.983 & 39.622 \\
\hline $\begin{array}{l}\text { Group which } \\
\text { had changes in } \\
\text { the signals }\end{array}$ & -0.212 & 0.068 & 2.211 & 4.891 & -4.765 & 36.143 \\
\hline $\begin{array}{l}\text { Group which } \\
\text { had only } \\
\text { negative } \\
\text { changes }\end{array}$ & -0.223 & 0.062 & 2.221 & 4.934 & -5.072 & 39.602 \\
\hline $\begin{array}{l}\text { Group which } \\
\text { had only } \\
\text { positive changes }\end{array}$ & -0.111 & 0.079 & 2.020 & 4.081 & -5.198 & 44.061 \\
\hline $\begin{array}{l}\text { Group which } \\
\text { had high } \\
\text { number of } \\
\text { positive changes }\end{array}$ & -0.154 & 0.082 & 2.174 & 4.730 & -4.797 & 37.385 \\
\hline $\begin{array}{l}\text { Group which } \\
\text { had high } \\
\text { number of } \\
\text { negative } \\
\text { changes }\end{array}$ & -0.436 & 0.018 & 2.567 & 6.594 & -4.696 & 32.683 \\
\hline $\begin{array}{l}\text { Group which } \\
\text { had equal } \\
\text { number of } \\
\text { positive and } \\
\text { negative } \\
\text { changes }\end{array}$ & -0.337 & 0.041 & 2.396 & 5.741 & -4.221 & 27.800 \\
\hline
\end{tabular}


Table 4: Analysts' forecast errors

\begin{tabular}{|c|c|c|c|c|}
\hline VARIABLES & whole sample & low & mixed & high \\
\hline FcErrLag & $\begin{array}{c}-0.041^{* * *} \\
(0.003)\end{array}$ & $\begin{array}{c}-0.055^{* * *} \\
(0.0060)\end{array}$ & $\begin{array}{c}-0.036^{* * *} \\
(0.008)\end{array}$ & $\begin{array}{c}-0.043^{* * *} \\
(0.005)\end{array}$ \\
\hline TotScore & $\begin{array}{c}-0.012^{* * *} \\
(0.004)\end{array}$ & $\begin{array}{c}-0.014^{*} \\
(0.008)\end{array}$ & $\begin{array}{c}0.009 \\
(0.012)\end{array}$ & $\begin{array}{l}-0.007 \\
(0.007)\end{array}$ \\
\hline sdTotScore & $\begin{array}{c}-0.091^{* * *} \\
(0.030)\end{array}$ & $\begin{array}{l}0.120^{*} \\
(0.062)\end{array}$ & $\begin{array}{c}-0.280^{* * *} \\
(0.094)\end{array}$ & $\begin{array}{l}-0.032 \\
(0.061)\end{array}$ \\
\hline BrSize & $\begin{array}{c}-0.037^{* *} \\
(0.017)\end{array}$ & $\begin{array}{c}-0.087^{* * *} \\
(0.031)\end{array}$ & $\begin{array}{l}-0.018 \\
(0.051)\end{array}$ & $\begin{array}{c}0.003 \\
(0.038)\end{array}$ \\
\hline FcAge & $\begin{array}{c}0.005^{* * *} \\
(0.000)\end{array}$ & $\begin{array}{c}0.005^{* * *} \\
(0.000)\end{array}$ & $\begin{array}{c}0.005^{* * *} \\
(0.000)\end{array}$ & $\begin{array}{c}0.005^{* * *} \\
(0.000)\end{array}$ \\
\hline$F c F r$ & $\begin{array}{l}-0.005 \\
(0.003)\end{array}$ & $\begin{array}{c}0.006 \\
(0.005)\end{array}$ & $\begin{array}{c}-0.018^{*} \\
(0.009)\end{array}$ & $\begin{array}{l}-0.007 \\
(0.006)\end{array}$ \\
\hline GenExp & $\begin{array}{c}0.001^{* * *} \\
(0.000)\end{array}$ & $\begin{array}{c}0.001^{* * *} \\
(0.000)\end{array}$ & $\begin{array}{c}0.001 \\
(0.001)\end{array}$ & $\begin{array}{c}0.000 \\
(0.000)\end{array}$ \\
\hline FirmExp & $\begin{array}{c}0.002 \\
(0.003)\end{array}$ & $\begin{array}{c}0.013 * * \\
(0.006)\end{array}$ & $\begin{array}{c}-0.016^{*} \\
(0.009)\end{array}$ & $\begin{array}{l}-0.007 \\
(0.006)\end{array}$ \\
\hline NumFirm & $\begin{array}{c}0.003^{* * *} \\
(0.001)\end{array}$ & $\begin{array}{c}0.002 \\
(0.002)\end{array}$ & $\begin{array}{l}0.005^{*} \\
(0.003)\end{array}$ & $\begin{array}{c}0.007 * * * \\
(0.002)\end{array}$ \\
\hline MomEarn & $\begin{array}{c}-0.280^{* * *} \\
(0.012)\end{array}$ & $\begin{array}{c}-0.280^{* * *} \\
(0.017)\end{array}$ & $\begin{array}{c}-0.350 * * * \\
(0.053)\end{array}$ & $\begin{array}{c}-0.300^{* * *} \\
(0.024)\end{array}$ \\
\hline RevEarn & $\begin{array}{c}0.11^{* * *} \\
(0.009)\end{array}$ & $\begin{array}{c}0.100^{* * *} \\
(0.013)\end{array}$ & $\begin{array}{c}0.100 \\
(0.065)\end{array}$ & $\begin{array}{c}0.110^{* * *} \\
(0.016)\end{array}$ \\
\hline FundSent & $\begin{array}{c}-0.025^{* * *} \\
(0.001)\end{array}$ & $\begin{array}{c}-0.022^{* * *} \\
(0.002)\end{array}$ & $\begin{array}{c}-0.019 * * * \\
(0.003)\end{array}$ & $\begin{array}{c}-0.028^{* * *} \\
(0.002)\end{array}$ \\
\hline ResSent & $\begin{array}{c}-0.013^{* * *} \\
(0.001)\end{array}$ & $\begin{array}{c}-0.008^{* * *} \\
(0.001)\end{array}$ & $\begin{array}{c}-0.011^{* * *} \\
(0.002)\end{array}$ & $\begin{array}{c}-0.020^{* * *} \\
(0.002)\end{array}$ \\
\hline Observations & 464,873 & 116,209 & 44,171 & 120,150 \\
\hline R-squared & 0.043 & 0.051 & 0.040 & 0.042 \\
\hline
\end{tabular}

Robust standard errors in parentheses

$* * * \mathrm{p}<0.01,{ }^{* *} \mathrm{p}<0.05,{ }^{*} \mathrm{p}<0.1$ 
Table 5: Managers' forecast error

\begin{tabular}{|c|c|c|c|c|}
\hline VARIABLES & whole sample & low & mixed & high \\
\hline TotScore & $\begin{array}{c}0.053^{* * *} \\
(0.003)\end{array}$ & $\begin{array}{l}-0.002 \\
(0.009)\end{array}$ & $\begin{array}{c}-0.142^{* * *} \\
(0.019)\end{array}$ & $\begin{array}{c}0.243^{* * *} \\
(0.013)\end{array}$ \\
\hline$s d S c$ & $\begin{array}{c}-0.267^{* * *} \\
(0.016)\end{array}$ & $\begin{array}{c}-0.096^{*} \\
(0.054)\end{array}$ & $\begin{array}{c}0.216^{* * *} \\
(0.031)\end{array}$ & $\begin{array}{c}-0.744^{* * *} \\
(0.043)\end{array}$ \\
\hline$s d A n F c$ & $\begin{array}{c}-0.733^{* * *} \\
(0.071)\end{array}$ & $\begin{array}{c}-0.104 \\
(0.106)\end{array}$ & $\begin{array}{c}-1.473^{* * *} \\
(0.283)\end{array}$ & $\begin{array}{c}-2.596^{* * *} \\
(0.187)\end{array}$ \\
\hline AnBias & $\begin{array}{c}-0.013^{* * *} \\
(0.003)\end{array}$ & $\begin{array}{c}0.005 \\
(0.003)\end{array}$ & $\begin{array}{c}0.008 \\
(0.010)\end{array}$ & $\begin{array}{c}-0.033^{* * *} \\
(0.007)\end{array}$ \\
\hline AnFcErrPred & $\begin{array}{c}-0.025^{* * *} \\
(0.005)\end{array}$ & $\begin{array}{c}-0.009^{* *} \\
(0.004)\end{array}$ & $\begin{array}{c}-0.038^{* * *} \\
(0.012)\end{array}$ & $\begin{array}{c}-0.081^{* * *} \\
(0.013)\end{array}$ \\
\hline FundSent & $\begin{array}{c}-0.005^{* * *} \\
(0.000)\end{array}$ & $\begin{array}{c}-0.003^{* * *} \\
(0.000)\end{array}$ & $\begin{array}{c}-0.004^{* * *} \\
(0.001)\end{array}$ & $\begin{array}{c}-0.009^{* * *} \\
(0.000)\end{array}$ \\
\hline ResSent & $\begin{array}{c}-0.001^{* * *} \\
(0.000)\end{array}$ & $\begin{array}{c}0.001 \\
(0.001)\end{array}$ & $\begin{array}{c}0.007^{* * *} \\
(0.001)\end{array}$ & $\begin{array}{c}-0.012^{* * *} \\
(0.001)\end{array}$ \\
\hline Ret & $\begin{array}{c}1.177^{* * *} \\
(0.172)\end{array}$ & $\begin{array}{c}1.683^{* * *} \\
(0.294)\end{array}$ & $\begin{array}{c}0.223 \\
(0.391)\end{array}$ & $\begin{array}{c}0.136 \\
(0.427)\end{array}$ \\
\hline sdRet & $\begin{array}{c}-1.785^{* * *} \\
(0.173)\end{array}$ & $\begin{array}{c}-7.646^{* * *} \\
(0.352)\end{array}$ & $\begin{array}{c}-3.734^{* * *} \\
(0.485)\end{array}$ & $\begin{array}{c}4.074^{* * *} \\
(0.414)\end{array}$ \\
\hline Vol & $\begin{array}{c}-0.001^{* * *} \\
(0.000)\end{array}$ & $\begin{array}{c}0.007^{* * *} \\
(0.001)\end{array}$ & $\begin{array}{c}-0.004^{* * *} \\
(0.001)\end{array}$ & $\begin{array}{c}-0.006^{* * *} \\
(0.001)\end{array}$ \\
\hline sdVol & $\begin{array}{c}0.001^{* * *} \\
(0.000)\end{array}$ & $\begin{array}{c}-0.003^{* * *} \\
(0.001)\end{array}$ & $\begin{array}{c}0.002^{* * *} \\
(0.001)\end{array}$ & $\begin{array}{c}-0.001 \\
(0.001)\end{array}$ \\
\hline AbnVol & $\begin{array}{c}0.000^{* * *} \\
(0.000)\end{array}$ & $\begin{array}{c}0.000^{* * *} \\
(0.000)\end{array}$ & $\begin{array}{c}-0.000^{* * *} \\
(0.000)\end{array}$ & $\begin{array}{c}0.000 * * * \\
(0.000)\end{array}$ \\
\hline$B A S p r$ & $\begin{array}{c}0.007 \\
(0.009)\end{array}$ & $\begin{array}{c}0.186^{* * *} \\
(0.023)\end{array}$ & $\begin{array}{c}-0.155^{* * *} \\
(0.033)\end{array}$ & $\begin{array}{c}0.106^{* * *} \\
(0.014)\end{array}$ \\
\hline$s d B A S p r$ & $\begin{array}{c}-0.304^{* * *} \\
(0.019)\end{array}$ & $\begin{array}{c}0.040 \\
(0.034)\end{array}$ & $\begin{array}{l}-0.040 \\
(0.059)\end{array}$ & $\begin{array}{c}-0.809^{* * *} \\
(0.045)\end{array}$ \\
\hline sdPrc & $\begin{array}{c}0.015^{* * *} \\
(0.000)\end{array}$ & $\begin{array}{c}0.020^{* * *} \\
(0.001)\end{array}$ & $\begin{array}{c}0.006^{* * *} \\
(0.001)\end{array}$ & $\begin{array}{c}0.021^{* * *} \\
(0.001)\end{array}$ \\
\hline InsTrans & $\begin{array}{c}1.475^{* * *} \\
(0.064)\end{array}$ & $\begin{array}{c}0.189^{* * *} \\
(0.051)\end{array}$ & $\begin{array}{c}0.374 \\
(0.253)\end{array}$ & $\begin{array}{c}2.245^{* * *} \\
(0.076)\end{array}$ \\
\hline$d L o s s$ & $\begin{array}{c}-0.113^{* * *} \\
(0.009)\end{array}$ & $\begin{array}{c}0.005 \\
(0.016)\end{array}$ & $\begin{array}{c}-0.328^{* * *} \\
(0.038)\end{array}$ & $\begin{array}{c}-0.299 * * * \\
(0.019)\end{array}$ \\
\hline$d \operatorname{LossFc}$ & $\begin{array}{c}0.200^{* * *} \\
(0.012)\end{array}$ & $\begin{array}{c}0.136^{* * *} \\
(0.026)\end{array}$ & $\begin{array}{c}0.229 * * * \\
(0.042)\end{array}$ & $\begin{array}{c}0.233^{* * *} \\
(0.024)\end{array}$ \\
\hline DifFc & $\begin{array}{c}2.368^{* * *} \\
(0.009)\end{array}$ & $\begin{array}{c}2.458^{* * *} \\
(0.021)\end{array}$ & $\begin{array}{c}2.320^{* * *} \\
(0.027)\end{array}$ & $\begin{array}{c}2.240^{* * *} \\
(0.017)\end{array}$ \\
\hline$d B a d N e w s * N e w s$ & $\begin{array}{c}-2.174^{* * *} \\
(0.029)\end{array}$ & $\begin{array}{c}-2.384^{* * *} \\
(0.037)\end{array}$ & $\begin{array}{c}-1.692^{* * *} \\
(0.124)\end{array}$ & $\begin{array}{c}-1.208^{* * *} \\
(0.082)\end{array}$ \\
\hline
\end{tabular}


Table 5 (continued): Managers' forecast error

\begin{tabular}{lcccc}
\hline & & & & \\
VARIABLES & whole sample & low & mixed & high \\
\hline \multirow{2}{*}{ FcHor } & $-0.001^{* * *}$ & $0.001^{* * *}$ & -0.000 & $-0.002^{* * *}$ \\
& $(0.000)$ & $(0.000)$ & $(0.000)$ & $(0.000)$ \\
IndConc & $0.068^{* * *}$ & 0.003 & $-0.117^{* * *}$ & $0.038^{* * *}$ \\
& $(0.006)$ & $(0.009)$ & $(0.015)$ & $(0.009)$ \\
Size & $0.039^{* * *}$ & $0.045^{* * *}$ & $0.034^{* * *}$ & $0.024^{* * *}$ \\
& $(0.002)$ & $(0.002)$ & $(0.004)$ & $(0.004)$ \\
Const & $0.161^{* * *}$ & -0.036 & $0.743^{* * *}$ & 0.076 \\
& $(0.021)$ & $(0.031)$ & $(0.097)$ & $(0.051)$ \\
\hline Observations & 278,542 & 69,759 & 32,019 & 83,975 \\
R-squared & 0.258 & 0.309 & 0.531 & 0.238 \\
\hline
\end{tabular}

Robust standard errors in parentheses

*** $\mathrm{p}<0.01,{ }^{*} * \mathrm{p}<0.05,{ }^{*} \mathrm{p}<0.1$ 
Table 6: Analysts' forecast revision

\begin{tabular}{|c|c|c|c|c|}
\hline VARIABLES & whole & low & mixed & high \\
\hline ManFc & $\begin{array}{c}0.041^{* * *} \\
(0.002)\end{array}$ & $\begin{array}{c}0.043^{* * *} \\
(0.003)\end{array}$ & $\begin{array}{c}0.044^{* * *} \\
(0.004)\end{array}$ & $\begin{array}{c}0.044^{* * * *} \\
(0.003)\end{array}$ \\
\hline ManFcRan & $\begin{array}{l}-0.025 \\
(0.019)\end{array}$ & $\begin{array}{c}-0.078 * * \\
(0.035)\end{array}$ & $\begin{array}{c}-0.110^{* *} \\
(0.053)\end{array}$ & $\begin{array}{l}-0.027 \\
(0.025)\end{array}$ \\
\hline ManFcRanLow & $\begin{array}{c}0.190^{* * *} \\
(0.068)\end{array}$ & $\begin{array}{c}0.140 * * * \\
(0.029)\end{array}$ & $\begin{array}{c}1.270^{* *} \\
(0.610)\end{array}$ & $\begin{array}{c}0.074 \\
(0.290)\end{array}$ \\
\hline ManErr & $\begin{array}{c}0.930^{* * *} \\
(0.068)\end{array}$ & $\begin{array}{c}1.040^{* * *} \\
(0.130)\end{array}$ & $\begin{array}{c}0.560^{* *} \\
(0.220)\end{array}$ & $\begin{array}{c}0.720^{* * *} \\
(0.097)\end{array}$ \\
\hline TotScore & $\begin{array}{c}0.002^{* * *} \\
(0.001)\end{array}$ & $\begin{array}{c}0.010 * * * \\
(0.003)\end{array}$ & $\begin{array}{c}0.004 \\
(0.007)\end{array}$ & $\begin{array}{l}-0.001 \\
(0.001)\end{array}$ \\
\hline$s d S c$ & $\begin{array}{l}-0.002 \\
(0.004)\end{array}$ & $\begin{array}{c}-0.087^{* * *} \\
(0.014)\end{array}$ & $\begin{array}{l}-0.001 \\
(0.009)\end{array}$ & $\begin{array}{c}0.022^{* * *} \\
(0.008)\end{array}$ \\
\hline$s d A n F c$ & $\begin{array}{c}-0.970^{* * *} \\
(0.048)\end{array}$ & $\begin{array}{c}-0.960^{* * *} \\
(0.051)\end{array}$ & $\begin{array}{c}-1.080^{* * *} \\
(0.078)\end{array}$ & $\begin{array}{c}-1.140^{* * *} \\
(0.047)\end{array}$ \\
\hline RelPrecis & $\begin{array}{c}0.001^{* * *} \\
(0.000)\end{array}$ & $\begin{array}{c}0.001^{* * *} \\
(0.000)\end{array}$ & $\begin{array}{c}0.002^{* * *} \\
(0.001)\end{array}$ & $\begin{array}{c}0.000 \\
(0.000)\end{array}$ \\
\hline FundSent & $\begin{array}{c}-0.000^{* * *} \\
(0.000)\end{array}$ & $\begin{array}{c}-0.000^{* * *} \\
(0.000)\end{array}$ & $\begin{array}{c}-0.001^{* * *} \\
(0.000)\end{array}$ & $\begin{array}{l}-0.000 \\
(0.000)\end{array}$ \\
\hline ResSent & $\begin{array}{c}0.001^{* * *} \\
(0.000)\end{array}$ & $\begin{array}{c}0.001^{* * *} \\
(0.000)\end{array}$ & $\begin{array}{c}0.001^{* * *} \\
(0.000)\end{array}$ & $\begin{array}{c}0.001^{* * *} \\
(0.000)\end{array}$ \\
\hline Ret & $\begin{array}{c}0.600^{* * *} \\
(0.031)\end{array}$ & $\begin{array}{c}0.620^{* * *} \\
(0.061)\end{array}$ & $\begin{array}{c}0.560^{* * *} \\
(0.093)\end{array}$ & $\begin{array}{c}0.530^{* * *} \\
(0.051)\end{array}$ \\
\hline sdRet & $\begin{array}{c}-0.140^{* * *} \\
(0.028)\end{array}$ & $\begin{array}{l}-0.047 \\
(0.054)\end{array}$ & $\begin{array}{c}-0.360 * * * \\
(0.068)\end{array}$ & $\begin{array}{c}0.053 \\
(0.042)\end{array}$ \\
\hline Vol & $\begin{array}{c}0.001^{* * *} \\
(0.000)\end{array}$ & $\begin{array}{c}0.000^{* * *} \\
(0.000)\end{array}$ & $\begin{array}{c}0.001^{* * *} \\
(0.000)\end{array}$ & $\begin{array}{c}0.001^{* * *} \\
(0.000)\end{array}$ \\
\hline$s d V o l$ & $\begin{array}{l}-0.000 \\
(0.000)\end{array}$ & $\begin{array}{l}-0.000 \\
(0.000)\end{array}$ & $\begin{array}{l}-0.000 \\
(0.000)\end{array}$ & $\begin{array}{c}-0.001^{* * *} \\
(0.000)\end{array}$ \\
\hline AbnVol & $\begin{array}{c}-0.000^{* * *} \\
(0.000)\end{array}$ & $\begin{array}{c}0.000 \\
(0.000)\end{array}$ & $\begin{array}{c}0.000^{* * *} \\
(0.000)\end{array}$ & $\begin{array}{c}-0.000^{* *} \\
(0.000)\end{array}$ \\
\hline$B A S p r$ & $\begin{array}{c}-0.009^{* * *} \\
(0.003)\end{array}$ & $\begin{array}{c}0.010 \\
(0.007)\end{array}$ & $\begin{array}{c}0.004 \\
(0.014)\end{array}$ & $\begin{array}{c}-0.040^{* * *} \\
(0.005)\end{array}$ \\
\hline$s d B A S p r$ & $\begin{array}{c}0.014^{* *} \\
(0.007)\end{array}$ & $\begin{array}{l}-0.010 \\
(0.012)\end{array}$ & $\begin{array}{c}-0.032^{* * *} \\
(0.012)\end{array}$ & $\begin{array}{c}0.060^{* * *} \\
(0.011)\end{array}$ \\
\hline$s d \operatorname{Prc}$ & $\begin{array}{c}-0.001^{* * *} \\
(0.000)\end{array}$ & $\begin{array}{c}-0.001^{* * *} \\
(0.000)\end{array}$ & $\begin{array}{c}-0.001^{* * *} \\
(0.000)\end{array}$ & $\begin{array}{c}-0.001^{* * *} \\
(0.000)\end{array}$ \\
\hline InsTrans & $\begin{array}{c}-0.270^{* * *} \\
(0.045)\end{array}$ & $\begin{array}{c}-0.250^{* * *} \\
(0.066)\end{array}$ & $\begin{array}{c}-0.980^{* * *} \\
(0.11)\end{array}$ & $\begin{array}{c}-0.085^{* * *} \\
(0.023)\end{array}$ \\
\hline$d$ Loss & $\begin{array}{c}0.009^{* * *} \\
(0.002)\end{array}$ & $\begin{array}{c}0.008^{* *} \\
(0.004)\end{array}$ & $\begin{array}{c}0.000 \\
(0.006)\end{array}$ & $\begin{array}{c}0.016^{* * *} \\
(0.003)\end{array}$ \\
\hline$d$ LossFc & $\begin{array}{c}-0.018^{* * *} \\
(0.002)\end{array}$ & $\begin{array}{c}-0.021^{* * *} \\
(0.005)\end{array}$ & $\begin{array}{c}-0.041^{* * *} \\
(0.009)\end{array}$ & $\begin{array}{c}-0.009^{* * *} \\
(0.003)\end{array}$ \\
\hline
\end{tabular}


Table 6 (continued): Analysts' forecast revision

\begin{tabular}{|c|c|c|c|c|}
\hline VARIABLES & whole & low & mixed & high \\
\hline$d B a d N e w s$ & $\begin{array}{c}0.013^{* * *} \\
(0.001)\end{array}$ & $\begin{array}{c}0.014^{* * *} \\
(0.002)\end{array}$ & $\begin{array}{c}0.012^{* * *} \\
(0.003)\end{array}$ & $\begin{array}{c}0.016^{* * *} \\
(0.001)\end{array}$ \\
\hline$d B a d N e w s * N e w s$ & $\begin{array}{c}0.062^{* * *} \\
(0.009)\end{array}$ & $\begin{array}{c}0.088^{* * *} \\
(0.013)\end{array}$ & $\begin{array}{c}0.120^{* * *} \\
(0.028)\end{array}$ & $\begin{array}{c}0.074^{* * *} \\
(0.023)\end{array}$ \\
\hline FcHor & $\begin{array}{c}0.000^{* * *} \\
(0.000)\end{array}$ & $\begin{array}{c}0.000^{* * *} \\
(0.000)\end{array}$ & $\begin{array}{c}0.000^{* * *} \\
(0.000)\end{array}$ & $\begin{array}{c}0.000^{* * *} \\
(0.000)\end{array}$ \\
\hline IndConc & $\begin{array}{c}-0.007^{* * *} \\
(0.001)\end{array}$ & $\begin{array}{l}-0.003 \\
(0.003)\end{array}$ & $\begin{array}{c}0.003 \\
(0.005)\end{array}$ & $\begin{array}{c}-0.016^{* * *} \\
(0.002)\end{array}$ \\
\hline Size & $\begin{array}{c}0.001^{* * *} \\
(0.000)\end{array}$ & $\begin{array}{c}0.001^{*} \\
(0.001)\end{array}$ & $\begin{array}{l}-0.000 \\
(0.001)\end{array}$ & $\begin{array}{c}0.003^{* * *} \\
(0.001)\end{array}$ \\
\hline BrSize & $\begin{array}{c}-0.003^{* *} \\
(0.001)\end{array}$ & $\begin{array}{l}-0.000 \\
(0.003)\end{array}$ & $\begin{array}{c}0.013^{* * *} \\
(0.004)\end{array}$ & $\begin{array}{c}-0.008^{* * *} \\
(0.003)\end{array}$ \\
\hline FcAge & $\begin{array}{c}-0.000^{* * *} \\
(0.000)\end{array}$ & $\begin{array}{c}-0.000^{* * *} \\
(0.000)\end{array}$ & $\begin{array}{c}-0.000^{* * *} \\
(0.000)\end{array}$ & $\begin{array}{c}-0.000^{* * *} \\
(0.000)\end{array}$ \\
\hline$F c F r$ & $\begin{array}{c}0.002^{* * *} \\
(0.000)\end{array}$ & $\begin{array}{c}0.001^{* * *} \\
(0.000)\end{array}$ & $\begin{array}{c}0.002^{* * *} \\
(0.000)\end{array}$ & $\begin{array}{c}0.002^{* * *} \\
(0.000)\end{array}$ \\
\hline GenExp & $\begin{array}{c}-0.000^{* * *} \\
(0.000)\end{array}$ & $\begin{array}{c}-0.000^{* * *} \\
(0.000)\end{array}$ & $\begin{array}{c}0.000 \\
(0.000)\end{array}$ & $\begin{array}{c}-0.000^{* * *} \\
(0.000)\end{array}$ \\
\hline FirmExp & $\begin{array}{c}0.000^{* *} \\
(0.000)\end{array}$ & $\begin{array}{c}0.000 \\
(0.000)\end{array}$ & $\begin{array}{l}-0.000 \\
(0.000)\end{array}$ & $\begin{array}{c}0.000^{* * *} \\
(0.000)\end{array}$ \\
\hline NumFirm & $\begin{array}{c}0.000 \\
(0.000)\end{array}$ & $\begin{array}{c}0.000^{*} \\
(0.000)\end{array}$ & $\begin{array}{c}-0.001^{* *} \\
(0.000)\end{array}$ & $\begin{array}{c}0.000 \\
(0.000)\end{array}$ \\
\hline Constant & $\begin{array}{c}-0.006 \\
(0.005) \\
\end{array}$ & $\begin{array}{l}-0.005 \\
(0.010)\end{array}$ & $\begin{array}{c}0.076^{* * *} \\
(0.029)\end{array}$ & $\begin{array}{c}-0.044^{* * *} \\
(0.009)\end{array}$ \\
\hline Observations & 40,970 & 10,352 & 4,848 & 12,475 \\
\hline R-squared & 0.318 & 0.299 & 0.444 & 0.348 \\
\hline
\end{tabular}

Robust standard errors in parentheses

${ }^{* * *} \mathrm{p}<0.01,{ }^{* *} \mathrm{p}<0.05,{ }^{*} \mathrm{p}<0.1$ 
Table 7: Analysts' forecast accuracy after revision

\begin{tabular}{|c|c|c|c|c|}
\hline \multirow[b]{2}{*}{ VARIABLES } & \multicolumn{4}{|c|}{ AnalBigErrScal_040613tex } \\
\hline & whole sample & low & mixed & high \\
\hline \multirow[t]{2}{*}{$M a n F c$} & $0.081^{* * *}$ & 0.038 & -0.110 & -0.013 \\
\hline & $(0.025)$ & $(0.050)$ & $(0.080)$ & $(0.050)$ \\
\hline \multirow[t]{2}{*}{ ManFcRan } & $0.930^{* * *}$ & 0.023 & $4.010 * * *$ & $0.820^{* *}$ \\
\hline & $(0.210)$ & $(0.470)$ & $(0.850)$ & $(0.340)$ \\
\hline \multirow[t]{2}{*}{ ManFcRanLow } & -1.040 & -0.390 & 6.000 & $-3.660 * *$ \\
\hline & $(0.810)$ & $(0.960)$ & $(15.400)$ & $(1.630)$ \\
\hline \multirow[t]{2}{*}{ ManErr } & $26.400 * * *$ & $28.900 * * *$ & $55.100 * * *$ & $20.500^{* * *}$ \\
\hline & $(1.210)$ & $(2.610)$ & $(5.780)$ & $(1.990)$ \\
\hline \multirow[t]{2}{*}{ TotScore } & $-0.049 * * *$ & $0.130 * *$ & 0.170 & 0.025 \\
\hline & $(0.013)$ & $(0.050)$ & $(0.180)$ & $(0.030)$ \\
\hline \multirow[t]{2}{*}{$s d S c$} & $0.300 * * *$ & -0.210 & -0.370 & -0.069 \\
\hline & $(0.081)$ & $(0.280)$ & $(0.240)$ & $(0.190)$ \\
\hline \multirow{2}{*}{ RelPrecis } & 0.000 & $0.012^{*}$ & $-0.025^{*}$ & 0.003 \\
\hline & $(0.004)$ & $(0.007)$ & $(0.013)$ & $(0.007)$ \\
\hline \multirow[t]{2}{*}{$s d A n F c$} & $-4.290 * * *$ & $-5.120 * * *$ & $-2.840 * * *$ & $-5.110 * * *$ \\
\hline & $(0.240)$ & $(0.520)$ & $(0.670)$ & $(0.480)$ \\
\hline \multirow{2}{*}{ FundSent } & $-0.006 * * *$ & $-0.005^{* * *}$ & $-0.005^{*}$ & $-0.015^{* * *}$ \\
\hline & $(0.001)$ & $(0.002)$ & $(0.003)$ & $(0.001)$ \\
\hline \multirow[t]{2}{*}{ ResSent } & $-0.015 * * *$ & $-0.011^{* * *}$ & $-0.016 * * *$ & $-0.024^{* * *}$ \\
\hline & $(0.001)$ & $(0.002)$ & $(0.004)$ & $(0.002)$ \\
\hline \multirow[t]{2}{*}{ Ret } & $-3.970 * * *$ & $-5.080 * * *$ & $-6.800 * * *$ & $-4.530^{* * *}$ \\
\hline & $(0.640)$ & (1.310) & $(2.310)$ & (1.140) \\
\hline \multirow[t]{2}{*}{ sdRet } & 0.740 & 0.940 & $-4.190 * *$ & -0.570 \\
\hline & $(0.520)$ & (1.140) & $(1.900)$ & $(0.950)$ \\
\hline \multirow[t]{2}{*}{ Vol } & $-0.006 * * *$ & $-0.009 * * *$ & $-0.018 * * *$ & $-0.008^{* * *}$ \\
\hline & $(0.001)$ & $(0.002)$ & $(0.004)$ & $(0.002)$ \\
\hline \multirow[t]{2}{*}{$s d V o l$} & $0.006^{* * *}$ & $0.008^{* * *}$ & $0.015^{* *}$ & $0.011^{* * *}$ \\
\hline & $(0.001)$ & $(0.003)$ & $(0.006)$ & $(0.003)$ \\
\hline \multirow[t]{2}{*}{ AbnVol } & $0.000^{* * *}$ & 0.000 & 0.000 & $0.000 * * *$ \\
\hline & $(0.000)$ & $(0.000)$ & $(0.000)$ & $(0.000)$ \\
\hline \multirow[t]{2}{*}{$B A S p r$} & -0.003 & $-0.440 * * *$ & 0.030 & 0.170 \\
\hline & $(0.059)$ & $(0.160)$ & $(0.260)$ & $(0.110)$ \\
\hline \multirow[t]{2}{*}{$s d B A S p r$} & -0.14 & -0.160 & $-1.340 * * *$ & $0.530^{* *}$ \\
\hline & $(0.12)$ & $(0.310)$ & $(0.350)$ & $(0.220)$ \\
\hline \multirow[t]{2}{*}{$s d \operatorname{Prc}$} & 0.001 & 0.008 & $-0.015^{*}$ & $0.014^{* * *}$ \\
\hline & $(0.003)$ & $(0.005)$ & $(0.009)$ & $(0.005)$ \\
\hline \multirow[t]{2}{*}{ InsTrans } & $2.960^{*}$ & 2.600 & 10.800 & 0.083 \\
\hline & $(1.540)$ & $(2.500)$ & $(6.690)$ & $(2.530)$ \\
\hline \multirow[t]{2}{*}{$d$ Loss } & $0.120^{* * *}$ & $0.390 * * *$ & $0.310 * * *$ & 0.067 \\
\hline & $(0.028)$ & $(0.060)$ & $(0.110)$ & $(0.053)$ \\
\hline \multirow[t]{2}{*}{$d$ LossFc } & $-0.065^{*}$ & -0.110 & -0.210 & 0.076 \\
\hline & $(0.037)$ & $(0.084)$ & $(0.15)$ & $(0.061)$ \\
\hline
\end{tabular}


Table 7 (continued): Analysts' forecast accuracy after revision

\begin{tabular}{|c|c|c|c|c|}
\hline \multirow[b]{2}{*}{ VARIABLES } & \multicolumn{4}{|c|}{ AnalBigErrScal_040613tex } \\
\hline & whole sample & low & mixed & high \\
\hline \multirow[t]{2}{*}{ dBadNews } & $-0.340^{* * *}$ & $-0.290 * * *$ & $-0.300^{* * *}$ & $-0.290 * * *$ \\
\hline & $(0.017)$ & $(0.033)$ & $(0.057)$ & $(0.033)$ \\
\hline \multirow[t]{2}{*}{$d B a d N e w s * N e w s$} & -0.100 & -0.023 & $-1.130^{* *}$ & $-1.550^{* * *}$ \\
\hline & $(0.074)$ & $(0.140)$ & $(0.460)$ & $(0.320)$ \\
\hline \multirow[t]{2}{*}{ FcHor } & $0.001^{* * *}$ & $0.003^{* * *}$ & 0.001 & $0.001^{* *}$ \\
\hline & $(0.000)$ & $(0.000)$ & $(0.001)$ & $(0.000)$ \\
\hline \multirow[t]{2}{*}{ IndConc } & -0.033 & 0.014 & $0.190^{*}$ & 0.051 \\
\hline & $(0.031)$ & $(0.060)$ & $(0.110)$ & $(0.056)$ \\
\hline \multirow[t]{2}{*}{ Size } & $0.100^{* * *}$ & $0.078 * * *$ & $0.120^{* * *}$ & $0.110^{* * *}$ \\
\hline & $(0.007)$ & $(0.013)$ & $(0.025)$ & $(0.014)$ \\
\hline \multirow[t]{2}{*}{$B R S I Z E$} & -0.030 & -0.029 & 0.032 & -0.020 \\
\hline & $(0.026)$ & $(0.055)$ & $(0.088)$ & $(0.052)$ \\
\hline \multirow[t]{2}{*}{$F C A G E$} & $0.004^{* * *}$ & $0.003^{* * *}$ & $0.003^{* * *}$ & $0.002^{* * *}$ \\
\hline & $(0.000)$ & $(0.001)$ & $(0.001)$ & $(0.001)$ \\
\hline \multirow[t]{2}{*}{$F c F r$} & 0.002 & 0.004 & $-0.014^{*}$ & 0.004 \\
\hline & $(0.003)$ & $(0.006)$ & $(0.008)$ & $(0.005)$ \\
\hline \multirow[t]{2}{*}{ GenExp } & $0.000 * * *$ & $0.000 * * *$ & 0.000 & $0.000^{* * *}$ \\
\hline & $(0.000)$ & $(0.000)$ & $(0.000)$ & $(0.000)$ \\
\hline \multirow[t]{2}{*}{ FirmExp } & $-0.005^{* * *}$ & $-0.005 * * *$ & $-0.007 * * *$ & $-0.004^{* * *}$ \\
\hline & $(0.001)$ & $(0.001)$ & $(0.002)$ & $(0.001)$ \\
\hline \multirow[t]{2}{*}{ NumFirm } & 0.001 & -0.002 & 0.006 & 0.004 \\
\hline & $(0.002)$ & $(0.003)$ & $(0.005)$ & $(0.003)$ \\
\hline \multirow[t]{2}{*}{ Constant } & $-1.120 * * *$ & $-1.270^{* * *}$ & $-1.420^{*}$ & $-0.530^{* *}$ \\
\hline & $(0.096)$ & $(0.210)$ & $(0.730)$ & $(0.220)$ \\
\hline Observations & 41,783 & 10,542 & 4,938 & 12,707 \\
\hline Pseudo R-squared & 0.0581 & 0.0643 & 0.0706 & 0.1100 \\
\hline
\end{tabular}




\section{Working Paper Series}

ISSN 1211-3298

Registration No. (Ministry of Culture): E 19443

Individual researchers, as well as the on-line and printed versions of the CERGE-EI Working Papers (including their dissemination) were supported from institutional support RVO 67985998 from Economics Institute of the ASCR, v. v. i.

Specific research support and/or other grants the researchers/publications benefited from are acknowledged at the beginning of the Paper.

(c) luliia Brushko, 2013

All rights reserved. No part of this publication may be reproduced, stored in a retrieval system or transmitted in any form or by any means, electronic, mechanical or photocopying, recording, or otherwise without the prior permission of the publisher.

Published by

Charles University in Prague, Center for Economic Research and Graduate Education (CERGE) and

Economics Institute of the ASCR, v. v. i. (EI)

CERGE-El, Politických vězňu 7, 11121 Prague 1, tel.: +420 224005 153, Czech Republic.

Printed by CERGE-EI, Prague

Subscription: CERGE-EI homepage: http://www.cerge-ei.cz

Phone: + 420224005153

Email: office@cerge-ei.cz

Web: http://www.cerge-ei.cz

Editor: Marek Kapička

The paper is available online at http://www.cerge-ei.cz/publications/working_papers/.

ISBN 978-80-7343-302-4 (Univerzita Karlova. Centrum pro ekonomický výzkum a doktorské studium)

ISBN 978-80-7344-295-8 (Akademie věd České republiky. Národohospodářský ústav) 
CERGE-EI

P.O.BOX 882

Politických vězňů 7

11121 Praha 1

Czech Republic http://www.cerge-ei.cz 